C.E.M.A.

Av. Cordoba 374

1054 Capital Eederal

TE . 314-2269

FAX 314-1654

BANKS AND MACROECONOMIC DISTURBANCES UNDER PREDETERMINED EXCHANGE RATES

Sebastian Edwards

$Y$

Carlos A. Végh

Marzo 1997

$\mathrm{N}^{\circ} 115$ 


\title{
Banks and Macroeconomic Disturbances under Predetermined Exchange Rates*
}

\author{
Sebastian Edwards \\ UCLA and NBER \\ sedwards@agsm.ucla.edu
}

\author{
Carlos A. Végh \\ UCLA \\ cvegh@ucla.edu
}

\section{March 1997}

\begin{abstract}
As the recent Mexican crisis vividly illustrates, Latin American countries often go through boom-bust cycles caused by both domestic policies and external shocks. Such cycles are typically magnified by weak banking systems which intermediate large capital inflows. This paper develops a simple optimizing model to analyze how the banking sector affects the propagation of shocks. In particular, we show how the world business cycle and shocks to the banking system affect output and employment through fluctuations in bank credit. We also analyze the countercyclical use of reserve requirements. Econometric evidence for Chile and Mexico supports the main predictions of the model.
\end{abstract}

* Address correspondence to Sebastian Edwards, Department of Economics, UCLA, Box 951477, Los Angeles, CA 90095-1477. This paper was prepared for presentation at a conference on "Monetary Policy and Financial Markets," held in Studiennzentrum Gerzensee, Gerzensee, Switzerland, October 16-18, 1996. We are grateful to Amartya Lahiri, Ross Levine, Maurice Obstfeld, Charles Wyplosz, and seminar participants at Berkeley, CEMA, USC, UC Riverside, and Vanderbilt University for useful comments and discussions. Part of this research was carried out when Edwards visited CEMA (Buenos Aires, Argentina) in November 1996. We are indebted to Alejandro Jara for excellent research assistance. 


\section{Introduction}

In December 1994 Mexico devalued its currency and plunged, as it had twelve years earlier, into a deep financial crisis. Analysts, international civil servants and financial brokers throughout the world were stunned. Many asked rethorically "who lost Mexico?", and politicians tried to determine the degree of responsibility of the U.S. administration and of the multilateral organizations. ${ }^{1}$

In many ways it is surprising that so many analysts were shocked by this turn of events. The Mexican peso crisis of 1994 had a remarkable historical precedent: merely a dozen years earlier Chile suffered a prophetically similar debacle. During the 1970s, and under the rule of General Augusto Pinochet, Chile undertook major structural reforms characterized by a drastic opening of the economy, a sweeping privatization program, and a major deregulation effort aimed at creating a modern financial sector. In Chile, as in Mexico more than a decade later, the monetary authorities used a predetermined nominal exchange rate as an anchor in their efforts to eliminate inflation. Both countries were subject to very large capital inflows that were intermediated by weak banking systems. In both episodes there were major credit and consumption booms that generated a severe real exchange rate appreciation and a loss in exports' competitiveness.

In Chile and Mexico the banking sector played a fundamental role during both the euphoric period preceding the currency collapse, as well as in the propagation (and magnification) of the crisis. Initially, banks intermediated extremely large - and unsustainable - capital inflows and helped finance the consumption boom. When, largely as a result of exogenous shocks, capital inflows began to slow down, the demand for deposits declined significantly and banks ran into financial difficulties, making the situation even worse. When the crisis finally erupted, both countries experienced a large decline in output and a major increase in unemployment. ${ }^{2}$

While the banking system's role in the boom-bust cycles of Chile, Mexico,

${ }^{1}$ On the Mexican peso crisis of 1994, see, for example, Calvo (1995), Calvo and Mendoza (1995), Dornbusch, Goldfajn, and Valdes (1996), Mishkin (1995), and Sachs, Tornell, and Velasco (1995). For a review of some of the main issues involved in currency crises, see Obstfeld (1995).

${ }^{2}$ See Kaminsky and Reinhart (1995) for the empirical regularities associated with banking crises. 
and many other developing countries often figures prominently in policy discussions, it has been largely ignored in most formal analyzes of exchange rate-based stabilization. ${ }^{3}$ This paper develops a fully-optimizing theoretical model of a small open economy with predetermined exchange rates to analyze how the existence of (privately-owned) banks affects the way in which domestic policy shocks (i.e., changes in the rate of devaluation), shocks to world interest rates, and shocks to the financial sector impact on bank credit, deposits, interest rates, wages, and real activity. ${ }^{4}$

The model illustrates how the introduction of a (costly) banking activity into an otherwise standard open-economy model may dramatically alter the real effects of macroeconomic disturbances. Banking is costly in that resources must be used to maintain a given level of credit and deposits. As a benchmark, we study the case of costless banking and show how exchange rate-based stabilization cycles (i.e., perfectly anticipated temporary stabilizations) provoke cycles in consumption, but have no effect whatsoever on output and employment. In sharp contrast, when banking is costly, exchange rate-based stabilization cycles also lead to cycles in output and employment through changes in interest rate spreads and bank credit. This exercise thus provides a simple, general-equilibrium illustration of the "magnification role" played by the banking sector.

In the context of our model, we also examine the effectiveness of lowering reserve requirements in the face of negative external shocks, as most vividly illustrated by Argentina in early 1995. The main conclusion is that when shocks affect the economy only through the demand side (i.e., by altering the level of deposits in the banking system), changes in reserve requirements can be highly effective in preventing the contraction in credit and the ensuing real effects. The important practical caveat here is that policymakers must be willing to raise reserve requirements in good times. However, when shocks hit directly the banking system and are thus spread to both the supply side and the demand side of the economy, changes in reserve requirements can only "insulate" either consumption or production, but not both sectors at the same time. In fact, the only way to prevent a credit contraction during bad times (i..e., high world interest rates) would be to lower reserve requirements so much that the resulting increase in deposit rates generates a deposit and a consumption boom. Of course, such countercycli-

${ }^{3}$ On exchange-rate based stabilization, see, for example, Bruno (1993), Edwards (1993), and Végh (1992).

${ }^{4}$ Although we develop the model with the cases of Chile and Mexico (and possibly Argentina) in mind, the theoretical framework is quite general and could be applied to other cases. 
cal monetary policy would lead to consumption contraction in good times. These policy exercises thus illustrate the difficulties faced by policymakers in dealing with shocks that spread to the whole economy through the banking system. ${ }^{5}$

In the empirical part of the paper, we use monthly data from Chile and Mexico to evaluate both the transmission mechanisms built into the model and its main implications. We find that the hypothesis that changes in interest rates Grangercause industrial production (while the reverse is not true) cannot be rejected. The same is true of changes in the spread between lending and deposit rates. We then use standard VARs to analyze the response of the main variables to shocks to world interest rates, the rate of devaluation, and the spread between lending and deposit rates (which we take as a proxy of the theoretical shock to the banking system). We proceed in two stages: we first use VARs to assess the impact on domestic interest rates of innovations in the world interest rate and in the rate of devaluation. We then analyze how shocks to either domestic interest rates and the interest rate spread affect the economy. By and large, we view the data as supporting the main implications of the model. A temporary rise in domestic interest rates, for instance, leads to lower output, a higher interest rate spread, a lower ratio of deposits to credit, and higher lending rates. The data are thus consistent with the idea that the banking sector plays a key role in the propagation of macroeconomic disturbances.

We should point out that, in terms of channels of monetary transmission, our model is a close conceptual relative of the type of macromodels of credit transmission pioneered by Bernanke and Blinder $(1988,1992)$ (see the recent survey by Bernanke and Gertler (1995)). This line of work seeks to explain the potency of monetary policy through endogenous changes in the "external finance premium" (the wedge between the return to lenders and the cost faced by borrowers). In this light, our model stresses the "banking lending channel," whose starting point is the assumption that many firms in the economy are critically dependent on bank credit for their normal operations (i.e., they would have difficulties raising funds by issuing equity or commercial paper). We believe this channel might be particularly relevant in developing countries, where bank credit remains, by and large, the primary source of funds (see the evidence in Rojas-Suarez and Weisbrod (1994) and Catena (1996)). ${ }^{6}$

${ }^{5}$ For a related analysis, see Guidotti (1996) who examines the determination of the optimal reserve requirement in a stochastic environment.

${ }^{6}$ Our model is also related to an earlier literature on the contractionary effects of devaluation, which had as a distinctive feature the assumption of increasing marginal costs of borrowing due 
The paper is organized as follows. Section 2 develops the theoretical model. Sections 3 analyzes the effects of temporary stabilization. Section 4 examines the use of reserve requirements as a countercyclical policy tool. Section 5 deals with shocks to the banking system. Section 6 contains our empirical analysis. Section 7 concludes by discussing directions for further research.

\section{The model}

Consider a small open economy perfectly integrated with the rest of the world in both goods and capital markets. The economy faces a given (and constant) world real interest rate, $r$. There exists a single (tradable and non-storable) good in the world, which is produced with labor as the only input. The domestic price of the good, $P$, is given by the law of one price: $P_{t}=E_{t} P_{t}^{*}$, where $E_{t}$ is the nominal exchange rate (in units of domestic currency per unit of foreign currency) and $P_{t}^{*}$ is the foreign-currency price of the good. Real variables will be expressed in terms of the good.

The economy operates under predetermined exchange rates; that is, policymakers set the rate of devaluation, $\varepsilon_{t}\left(\equiv \dot{E}_{t} / E_{t}\right)$, and stand ready to exchange domestic money for international reserves (or viceversa) at the prevailing exchange rate. Domestic inflation is thus equal to $\varepsilon_{t}+\pi_{t}^{*}$, where $\pi_{t}^{*}\left(\equiv \dot{P}_{t}^{*} / P_{t}^{*}\right)$ is the foreign inflation rate. The Fischer equation holds in the rest of the world so that $r=i_{t}^{*}-\pi_{t}^{*}$, where $i_{t}^{*}$ is the foreign nominal interest rate. Perfect capital mobility implies that $i_{t}=i_{t}^{*}+\varepsilon_{t}$.

The structure of the model is as follows. ${ }^{7}$ There are four agents in this economy: households, firms, banks, and the government. Households, which own the firms and the banks, consume the good and provide labor. Households must use demand deposits to carry out transactions (through a deposit-in-advance constraint). Firms produce the only good by hiring labor. Firms need bank credit to pay the wage bill (through a credit-in-advance constraint). Banks finance their lending operations with deposits and external financing (a traded bond). On the asset side, banks lend to firms and hold cash as required reserves. All the mon-

to underdeveloped capital markets (see, for instance, Bruno (1979)). We do not deal, however, with issues related to the interaction between the financial sector and growth (see, for instance, King and Levine (1993)).

${ }^{7}$ The model incorporates a banking sector into an otherwise standard optimizing model of a small open economy with a labor-leisure choice, such as those used by Lahiri (1995), Rebelo and Végh (1995), and Roldos (1993) to analyze the real effects of exchange rate-based stabilization. 
etary base is held by banks since households do not use cash. The government's role is to set the rate of devaluation and the reserve-requirement ratio.

\subsection{Households}

The lifetime utility of the representative household is given by

$$
\int_{0}^{\infty}\left[\log \left(c_{t}\right)+\log \left(x_{t}\right)\right] \exp (-\beta t) d t
$$

where $c_{t}$ denotes consumption, $x_{t}$ is leisure, and $\beta(>0)$ is the subjective discount rate. ${ }^{8}$ The household is endowed with one unit of time. Labor supply is thus $1-x_{t}$.

Households hold two assets: domestic demand-deposits and an internationally traded bond. The household's financial wealth in real terms (denoted by $a^{h}$ ) is thus:

$$
a_{t}^{h}=b_{t}^{h}+d_{t},
$$

where $d_{t}$ and $b_{t}^{h}$ denote the real stocks of demand-deposits and bonds, respectively. Demand-deposits earn a nominal return of $i^{d}$. The traded bond earns a nominal return (in terms of domestic currency) of $i$. The household's flow constraint is given by

$$
\dot{a}_{t}^{h}=r a_{t}^{h}+w_{t}\left(1-x_{t}\right)+\Omega_{t}^{f}+\Omega_{t}^{b}+\tau_{t}-c_{t}-\left(i_{t}-i_{t}^{d}\right) d_{t},
$$

where $w_{t}$ is the real wage; $\Omega^{f}$ and $\Omega^{b}$ denote dividends from the firms and banks, respectively; and $\tau_{t}$ are lump-sum transfers from the government. The flow constraint (2.3) thus says that, at each point in time, households' income consists of the real return on its financial assets, $r a_{t}^{h}$, labor income, $w_{t}\left(1-x_{t}\right)$, dividends from the firms and the banks, $\Omega_{t}^{f}+\Omega_{t}^{b}$, and transfers from the government, $\tau_{t}$. The household's expenditures consist of consumption, $c_{t}$, and the opportunity cost of holding demand deposits, $\left(i_{t}-i_{t}^{d}\right) d_{t}$.

Households must hold demand deposits to carry out transactions. Formally, they are subject to a deposit-in-advance constraint:

$$
d_{t}=\alpha c_{t}
$$

${ }^{8}$ We choose logarithmic preferences to simplify the exposition; the same results would hold for any separable utility function. Non-separable preferences would introduce dynamics unrelated to the main issues at hand. 
whereby demand deposits are proportional to consumption. ${ }^{9}$

Integrating forward (2.3), imposing the no-Ponzi games condition and taking into account (2.4), we can write the household's lifetime budget constraint as:

$$
a_{0}^{h}+\int_{0}^{\infty}\left\{w_{t}\left(1-x_{t}\right)+\Omega_{t}^{f}+\Omega_{t}^{b}+\tau_{t}-c_{t}\left[1+\alpha\left(i_{t}-i_{t}^{d}\right)\right]\right\} \exp (-r t) d t=0
$$

The household's optimization problem consists in choosing $\left\{c_{t}, h_{t}\right\}_{t=0}^{\infty}$ so as to maximize lifetime utility (2.1), subject to (2.5), given its initial financial wealth, $a_{0}^{h}$, and the time paths of $w_{t}, i_{t}, i_{t}^{d}, \Omega_{t}^{f}, \Omega_{t}^{b}$, and $\tau_{t}$. The first-order conditions are

$$
\begin{gathered}
\frac{1}{c_{t}}=\lambda\left[1+\alpha\left(i_{t}-i_{t}^{d}\right)\right], \\
\frac{1}{x_{t}}=\lambda w_{t},
\end{gathered}
$$

where $\lambda$ is the (time-invariant) multiplier associated with constraint (2.5). ${ }^{10}$ Equation (2.6) indicates that, at an optimum, the household equates the marginal utility of consumption to the marginal utility of wealth times the effective price of the good. The effective price of the good is the sum of its market price (equal to unity) plus the opportunity cost of holding the demand deposits which are needed to purchase one unit of consumption, $\alpha\left(i_{t}-i_{t}^{d}\right)$. Condition (2.7) states that, at an optimum, the marginal utility of leisure is equal to the marginal utility of wealth times the real wage. Given the optimal choice of consumption, (2.4) determines the optimal path of demand-deposits.

\subsection{Firms}

The representative firm produces the good under a constant-returns-to scale technology, which transforms one unit of labor, $\ell_{t}$, into one unit of output, $y_{t}$ :

$$
y_{t}=\ell_{t}
$$

We assume that firms must use bank credit to pay the wage bill. Formally, firms face a "credit-in-advance" constraint:

${ }^{9}$ Since the analysis will focus on situations in which $i-i^{d}>0$, equation (2.4) will always hold as an equality at an optimum. For the derivation of cash-in-advance constraints in continuous time, see Feenstra (1985).

${ }^{10}$ As usual, it has been assumed that $\beta=r$ to eliminate inessential dynamics. 


$$
z_{t}=\gamma w_{t} \ell_{t}
$$

where $z_{t}$ denotes the real stock of bank credit and $\gamma$ is a positive parameter. In addition to bank credit (which is a liability), firms may hold bonds $\left(b^{f}\right)$. Firms' real financial wealth (capital) is thus:

$$
a_{t}^{f} \equiv b_{t}^{f}-z_{t}
$$
is

Since the firm must pay the lending rate, $i^{\ell}$, for bank credit, its flow constraint

$$
\dot{a}_{t}^{f}=r a_{t}^{f}+y_{t}-w_{t} \ell_{t}-\left(i_{t}^{\ell}-i_{t}\right) z_{t}-\Omega^{f} .
$$

The real cost of bank credit for the firm is $i_{t}^{\ell}-\left(\varepsilon_{t}+\pi_{t}^{*}\right)$, which can be rewritten as $r_{t}+i_{t}^{\ell}-i_{t}$. The term $\left(i_{t}^{\ell}-i_{t}\right) z_{t}$ in equation (2.10) thus represents the additional financial cost incurred by the firm for having to use bank credit to pay the wage bill. Integrating forward (2.10), imposing the appropriate no-Ponzi games condition, and taking into account (2.8) and (2.9), the present discounted value of the firm's dividends can be written as

$$
\int_{0}^{\infty} \Omega_{t}^{f} \exp (-r t) d t=a_{0}^{f}+\int_{0}^{\infty}\left\{\ell_{t}-w_{t} \ell_{t}\left[1+\gamma\left(i_{t}^{\ell}-i_{t}\right)\right]\right\} \exp (-r t) d t .
$$

The firm's objective is to choose a path of $\ell_{t}$ to maximize the present discounted value of dividends - given by the right-hand side of $(2.11)$ - for given paths of $w_{t}, i_{t}^{\ell}$, and $i_{t}$, and a given initial stock of net assets, $a_{0}^{f}$. The first-order condition is

$$
1=w_{t}\left[1+\gamma\left(i_{t}^{\ell}-i_{t}\right)\right]
$$

At an optimum, the firm equates the marginal productivity of labor, unity, to the marginal cost of a unit of labor, given by the right-hand side of equation (2.12). The latter comprises the real wage, $w_{t}$, plus the financial cost of the bank credit needed to pay the corresponding wage bill. Since the wage bill for a unit of labor is simply $w$, the firm needs bank credit in the amount $\gamma w_{t}$, whose financial cost is $w_{t} \gamma\left(i_{t}^{\ell}-i_{t}\right)$. ${ }^{11}$

${ }^{11}$ Note that in this model the optimal real allocations will be the same regardless of the time path of dividends, because households care only about the present discounted value of dividends from either firms or banks. If, to fix ideas, it was assumed that firms financed their operations through retained earnings (i.e., firms do not accumulate/decumulate net assets or issue new equity), then dividends would be given by $\Omega_{t}^{f}=y_{t}-w_{t} \ell_{t}-\left(i_{t}^{\ell}-i_{t}\right) z_{t}=0$. 


\subsection{Banks}

The role of the banks is to take deposits from households and lend to firms. The banking industry is assumed to be perfectly competitive. Banks' assets in real terms consist of (i) internationally-traded bonds $\left(b^{b}\right)$, (ii) credit to firms $(z)$, and (iii) high-powered money $(h)$. Banks' liabilities consist entirely of deposits $(d)$. Hence, denoting banks' total net assets (i.e., the bank's capital) by $a^{b}$, we have that:

$$
a_{t}^{b}=b_{t}^{b}+h_{t}+z_{t}-d_{t} .
$$

It will be assumed that banks need to use resources to "produce" credit and deposits. ${ }^{12}$ Such a formulation captures the idea that, in practice, banks must carry out a variety of costly activities to maintain a given level of loans and deposits (such as evaluating creditors, managing deposits, renting buildings, maintaining ATM's, and so on). Formally, banks use tradable resources (denoted by $q$ ) to jointly produce deposits and loans through a production function implicitely defined by $H(z, d, q)$. Assuming that $H($.$) can be solved for q$, we obtain $q=\eta\left(z_{t}, d_{t}\right)$. This is a standard cost function, which is assumed to be strictly increasing, strictly convex, and linearly homogenous. ${ }^{13}$ It then satisfies, for $z>0$ and $d>0$,

$$
\eta(.)>0, \eta_{z}(.)>0, \eta_{d}(.)>0, \eta_{z z}(.)>0, \eta_{d d}(.)>0, \eta_{z d}(.)<0 \text {. }
$$

It also satisfies $\eta(0,0)=0, \eta_{z}(0, d)=0$, and $\eta_{d}(z, 0)=0$.

The bank's flow budget constraint is then given by:

$$
\dot{a}_{t}^{b}=r a_{t}^{b}+\left(i_{t}^{\ell}-i_{t}\right) z_{t}+\left(i_{t}-i_{t}^{d}\right) d_{t}-i_{t} h_{t}-\xi_{t} \eta\left(z_{t}, d_{t}\right)-\Omega_{t}^{b},
$$

where $\xi_{t}$ is a shock to the banks' non-financial costs. The real return on a unit of credit is $i_{t}^{\ell}-\left(\varepsilon_{t}+\pi_{t}^{*}\right)=r+\left(i_{t}^{\ell}-i_{t}\right)$, so the term $\left(i_{t}^{\ell}-i_{t}\right) z_{t}$ in $(2.13)$ denotes the real return on bank credit in excess of the world real interest rate. Put differently, since banks can always lend to the rest of the world (by buying bonds) at the rate

${ }^{12}$ As will become clear below, financial intermediation must be a costly activity for banks to play a non-trivial macroeconomic role. Models of costly banking include Diaz-Gimenez et al (1992), Fischer (1983), and Lucas (1993). We could have assumed, at the cost of complicating the model, that labor is also needed as an input in production (in addition to tradable resources).

${ }^{13}$ As usual, strict convexity is needed to ensure that second-order conditions for profit maximization are met. Linear homogeneity implies that loans and deposits are complements in the sense that $\eta_{z d}()<$.0 . 
$i_{t}, i_{t}^{\ell}-i_{t}$ is the spread earned by banks from lending domestically. Hereafter, we will refer to $i_{t}^{\ell}-i_{t}$ as the "lending spread."

The interest paid on deposits (in real terms) is $i_{t}^{d}-\left(\varepsilon_{t}+\pi_{t}^{*}\right)=r-\left(i_{t}-i_{t}^{d}\right)$. As we will see, in equilibrium, $i_{t}^{d}<i_{t}$. Hence, the term $\left(i_{t}-i_{t}^{d}\right) d_{t}$ in (2.13) indicates the gain to the bank (in real terms) of paying depositors less than the world real interest rate. Put differently, since banks can always borrow from the rest of the world (by selling bonds) at the rate $i_{t}, i_{t}-i_{t}^{d}$ is the spread earned by banks from borrowing domestically at a lower cost. In what follows, we will refer to $i_{t}-i_{t}^{d}$ as the "deposit spread." The term $i_{t} h_{t}$ is the opportunity cost of holding reserves.

Integrating forward (and imposing the no-Ponzi games condition):

$$
\int_{0}^{\infty} \Omega_{t}^{b} \exp (-r t) d t=a_{0}^{b}+\int_{0}^{\infty}\left[\left(i_{t}^{\ell}-i_{t}\right) z_{t}+\left(i_{t}-i_{t}^{d}\right) d_{t}-i_{t} h_{t}-\xi_{t} \eta\left(z_{t}, d_{t}\right)\right] \exp (-r t) d t
$$

The government imposes a reserve-requirement ratio, $\delta_{t}$. At an optimum, the bank will want to hold only required reserves (i.e., excess reserves will be zero). The required-reserves constraint is thus:

$$
h_{t}=\delta_{t} d_{t} .
$$

The bank chooses $\left\{z_{t}, d_{t}, h_{t}\right\}$ to maximize the present discounted value of dividends (given by the right-hand side of equation (2.14)), subject to (2.15), taking as given its initial capital, $a_{0}^{b}$; and the time paths of $i_{t}^{\ell}, i_{t}^{d}, i_{t}$, and $\delta_{t}$. In addition to (2.15), the first-order conditions are:

$$
\begin{gathered}
i_{t}^{\ell}=i_{t}+\xi_{t} \eta_{z}\left(\frac{z_{t}}{d_{t}}, 1\right), \\
i_{t}^{d}=\left(1-\delta_{t}\right) i_{t}-\xi_{t} \eta_{d}\left(1, \frac{d_{t}}{z_{t}}\right) .
\end{gathered}
$$

To gain insights into the implications of costly banking, it will prove useful to have as a benchmark the standard case of costless banking (i.e., the case in which $\left.\eta\left(z_{t}, d_{t}\right) \equiv 0\right)$. In that case, (2.16) and (2.17) reduce to:

$$
\begin{gathered}
i_{t}^{\ell}=i_{t}, \\
i_{t}^{d}=\left(1-\delta_{t}\right) i_{t} .
\end{gathered}
$$


In a competitive equilibrium with costless banking, banks would charge creditors the opportunity cost of funds (equation (2.18)), and pay depositors the cost of funds adjusted by the cost of holding required reserves (equation (2.19)).

When banking is costly, several noteworthy features follow immediately from (2.16) and (2.17). First, since the marginal cost of extending bank credit is positive, the lending rate, $i^{\ell}$, will always be above the cost of funds, $i$, (as follows from $(2.16)$ ). Second, the deposit rate, $i^{d}$, will always be below the cost of funds (adjusted by the required reserves ratio), $i(1-\delta)$, because the marginal cost of taking more deposits is positive (equation (2.17)). Costly banking has therefore the natural implication of introducing a wedge between the lending rate and the deposit rate. The interest rate spread, $i^{\ell}-i^{d}$, is thus higher in the case of costly banking.

As in the case of firms, the time path of $\Omega_{t}^{b}$ is irrelevant because households care only about the present discounted value of bank dividends. To fix ideas, we will assume that banks finance their operations through retained earnings and hold no capital (i.e., $a_{t}^{b}=0$ for all $t$ ). ${ }^{14}$ Since the banks hold no capital, it follows that

$$
h_{t}+z_{t}=-b_{t}^{b}+d_{t} .
$$

In general, the composition of the bank's assets (and liabilities) may change over time. We have written net foreign assets as a liability in (2.20) to stress a useful way of thinking about banks in this model. Suppose that $b^{b}<0$. Then, the bank is financing itself both domestically (through deposits) and by borrowing in international capital markets. At an optimum, both sources of financing are equally costly, as follows from (2.17).

\subsection{Government}

The government's monetary authority sets the path of the devaluation rate, $\varepsilon_{t}$, and the reserve-requirement ratio, $\delta_{t}$. On the fiscal side, the government receives interest on its net foreign assets, collects revenues from money creation, and gives lump-sum transfers to households. The government's flow constraint is given by:

$$
\dot{b}_{t}^{g}=r b_{t}^{g}+\dot{h}_{t}+\left(\varepsilon_{t}+\pi_{t}^{*}\right) h_{t}+\xi_{t} \eta\left(z_{t}, d_{t}\right)-\tau_{t} .
$$

${ }^{14}$ The implied dividend policy is $\Omega_{t}^{b}=\left(i_{t}^{\ell}-i_{t}\right) z_{t}-\left(i_{t}^{d}-i_{t}\right) d_{t}-i_{t} h_{t}-\xi_{t} \eta\left(z_{t}, d_{t}\right)$, which amounts to distributing as dividends the profits generated. Since the banking industry exhibits constant returns of scale, dividends will be zero at an optimum, as can be easily checked. 
The fact that $\xi_{t} \eta\left(z_{t}, d_{t}\right)$ appears in the government's budget constraint reflects the assumption that $\xi_{t} \eta\left(z_{t}, d_{t}\right)$ is a private cost for the banks but not a social cost. Formally, one can think of some federal agency providing (at zero cost) the monitoring and administrative services needed to run the banks. The profits of this federal agency are returned to households as lump-sum transfers. We make this assumption to keep the analysis clean and focus only on the distortions introduced by a costly banking system. ${ }^{15}$

The government's lifetime constraint is (imposing the no-Ponzi games condition):

$$
b_{0}^{g}+\int_{0}^{\infty}\left[\dot{h}_{t}+\left(\varepsilon_{t}+\pi_{t}^{*}\right) h_{t}+\xi_{t} \eta\left(z_{t}, d_{t}\right)-\tau_{t}\right] \exp (-r t) d t=0
$$

\subsection{Equilibrium conditions}

Labor market equilibrium implies that

$$
1-x_{t}=\ell_{t}
$$

Perfect capital mobility requires that the interest parity condition holds:

$$
i_{t}=i_{t}^{*}+\varepsilon_{t}
$$

where $i_{t}^{*}=r+\pi_{t}^{*}$.

The economy's flow constraint (i.e., the current account) follows from aggregating the flow constraints of the four sectors (households, firms, banks, and government), given by equations (2.3), (2.10),(2.13), and (2.21), and taking into account (2.23) and (2.24):

$$
\dot{k}_{t}=r k_{t}+1-x_{t}-c_{t}
$$

where $k\left(\equiv b^{h}+b^{f}+b^{b}+b^{g}\right)$ denotes the economy's net stock of bonds.

Similarly, the economy's resource constraint follows from combining the intertemporal budget constraint of the four sectors (equations (2.5), (2.11), (2.14) and $(2.22)$ ), taking into account (2.23) and (2.24):

${ }^{15}$ If $\eta\left(z_{t}, d_{t}\right)$ were a social cost, then the economy's real resources would be affected by the size of the banking system. While this may be a relevant consideration in high inflation countries with an "excessively" developed banking system (as may arguably be the case of Brazil), it is unrelated to the issues being analyzed here. 


$$
k_{0}+\int_{0}^{\infty}\left(1-x_{t}-c_{t}\right) \exp (-r t) d t=0 .
$$

\subsection{Perfect foresight equilibrium}

Suppose that the time paths for $t \in[0, \infty)$ of the rate of devaluation, $\varepsilon_{t}$, the world nominal interest rate, $i_{t}^{*}$, shocks to banking costs, $\xi_{t}$, and the reserve-requirements ratio, $\delta_{t}$, are perfectly known by all actors in this economy. We now derive some general characteristics of the behavior of the main endogenous variables along such a perfect foresight equilibrium path. First, note that by combining (2.7) and (2.12), we obtain:

$$
\frac{1}{x_{t}}=\frac{\lambda}{1+\gamma\left(i_{t}^{\ell}-i_{t}\right)} .
$$

Since $\lambda$ remains unchanged along a perfect-foresight equilibrium path, leisure will change only if the lending spread, $i_{t}^{\ell}-i_{t}$, changes. Intuitively, if the lending spread increases, the firm's cost of hiring labor increases, and thus the real wage falls (equation (2.12)). The fall in the real wage induces the household to work less (i.e., leisure increases).

Combining (2.26) with the household's first-order condition for consumption (equation (2.6)) yields:

$$
\frac{x_{t}}{c_{t}}=\left[1+\alpha\left(i_{t}-i_{t}^{d}\right)\right]\left[1+\gamma\left(i_{t}^{\ell}-i_{t}\right)\right] .
$$

Equation (2.27), which equates the marginal rate of substitution between consumption and leisure (left-hand side) to the relative price of consumption faced by the non-financial private sector (right-hand side), serves to illustrate the distortions present in this economy. In a first-best equilibrium, the relative price of consumption would be unity (the social cost of consumption). There are two distortions which make the relative price of consumption higher than one. The first is the standard distortion in cash-in-advance models, $1+\alpha\left(i_{t}-i_{t}^{d}\right)$. Although in this model households use interest-bearing money (i.e., deposits), this distortion is still present because deposits do not earn the opportunity cost of funds, $i_{t}$. The second distortion, $1+\gamma\left(i_{t}^{\ell}-i_{t}\right)$, results from the firm's need to use bank credit which, in equilibrium, is more expensive than the opportunity cost of funds. In response, the firm hires less labor than it would otherwise. Thus, the credit-in-advance constraint combined with costly banking reinforces the distortion introduced by the 
deposit-in-advance constraint, leading to less consumption and less employment than in a first-best equilibrium.

\subsection{The credit market}

Since the credit market is the key mechanism highlighted by our model, it is worth looking at it in some detail. Figure 1 offers a graphical illustration of credit market equilibrium. The bank's first-order condition (2.16) can be viewed as implicitly defining an upward-sloping supply of credit for a given level of deposits. This schedule slopes upwards because, for a given level of deposits, banks will extend more credit only if the lending spread is higher. On the demand side, the firm's demand for credit follows from combining the credit-in-advance constraint (2.9) with the firm's first order condition (2.12) to obtain:

$$
z_{t}=\frac{\gamma \ell_{t}}{1+\gamma\left(i_{t}^{\ell}-i_{t}\right)} .
$$

For a given level of employment, the demand for credit is a decreasing function of the lending spread, $\boldsymbol{i}_{t}^{\ell}-i_{\boldsymbol{t}}$. A higher lending spread increases the financial cost of hiring additional labor, which reduces the real wage and thus the wage bill. A lower wage bill reduces the demand for credit. For a given lending spread, lower employment also reduces the wage bill and hence the demand for credit.

For graphical purposes, it is useful to derive the demand for credit from the non-financial private sector (i.e., firms-cum-households). The household's supply of labor, given by (2.7), depends on the real wage and hence, through (2.12), on the lending spread. The higher the lending spread, the lower the real wage, and hence the lower the labor supply along a perfect foresight equilibrium path. Combining (2.7), (2.9), (2.12), and imposing labor market equilibrium (equation (2.23)), we obtain:

$$
z_{t}=\frac{\gamma}{1+\gamma\left(i_{t}^{\ell}-i_{t}\right)}-\frac{\gamma}{\lambda} .
$$

Along a perfect foresight equilibrium path, the non-financial private sector's demand for credit is a function only of the lending spread. A higher lending spread decreases credit demand because (i) it reduces labor effort and (ii) it reduces the wage bill for a given labor effort. This downward-sloping curve is the one depicted in Figure 1. For a given level of deposits, point A represents the credit-market 
equilíbrium at time $t^{16}$

Figure 1 also shows the equilibrium for the case of costless banking. In that case, the bark's supply of credit is infinitely elastic at the point at which the lending spread is zero, as made clear by $(2.18)$. Credit market equilibrium would thus obtain at point $\mathrm{B}$. Hence, in the costless banking case, credit is higher and the lending spread lower than in the costly banking case.

\section{Temporary stabilization}

This section illustrates the role of the banking system in the transmission of domestic policies by studying the perfect-foresight equilibrium path of the economy for a non-constant path of $\varepsilon$. The idea is to explore how the banking sector affects the transmission of inflation and stabilization cycles, which typically characterize developing countries. We will thus assume that, along a perfect foresight path, periods of low inflation (low $\varepsilon$ ) are followed by petiods of high inflation (high $\varepsilon)$. To fix ideas, we will think of low inftation periods as "good times" and of high inflation periods as "bad times." Since interest parity holds (recall equation $(2.24)$ ), the domestic nominal interest rate rises and falls in tandem with the rate of devaluation.

For the sake of concreteness, we will refer to the path illustrated in Figure 2, Panel $A$. The nominal interest rate can take only two values: high and low. As of time 0 (the "present"), $i$ is at its high value and remains there until time $T$. A stabilization is then implemented and the nominal interest rate falls until time 2T. It then increases to its high value and so on. Since the model has no intrinsic dynamics, it is enough to characterize the equilibrium for the "bigh" and "low" levels. The cycle then repeats itself indefinitely.

\section{3.x. Costless banking}

As a benchmark, let us examine the economy's equilibrium path in the case of costless banks (i.e., $\eta(.) \equiv 0$ ). The reserve requiremente ratio is assumed to be coristant over time; that is, $\delta_{t}=\delta$. In this case, as indicated by (2.18) and (2.19), $i_{t}^{\ell}-i_{t}=0$ and $i_{t}-i_{t}^{t}=\delta i_{t}$. Since the lending spread is always zero, it follows from (2.26) that, along an equilibrium path, leisure (and thus employment) is always

\footnotetext{
${ }^{16}$ Of course, in gekeral equilibrium the level of deposits will be determined simultaneously with all other variables. Conceptually, however, it will prove useful to think of the credit market as taking as given the level of deposits.
} 
the same regardless of the path of $\varepsilon$. Intuitively, since the firm's financial costs do not vary over the cycle, the real wage is always equal to the marginal productivity of labor (unity). There is thus no incentive for the household to change its supply of labor.

On the other hand, the deposit spread, $i_{t}-i_{t}^{d}\left(=\delta i_{t}\right)$, is high when $\varepsilon$ (and thus $i$ ) is high. Hence, as follows from (2.6), consumption will be high in good times (i.e., when $\varepsilon$ is low) and low in bad times (i.e., when $\varepsilon$ is high). Intuitively, since good times entail a lower cost of funds for banks, deposit rates will have to fall. Due to the existence of reserve requirements, however, the deposit rate falls by less than $i$, resulting in a smaller deposit spread. The resulting reduction in the effective price of consumption leads to higher consumption. Since output is constant, the trade balance will be in deficit. On the other hand, bad times will be characterized by a higher deposit spread, lower consumption, and a trade surplus.

What happens to credit and deposits over the business cycle? Credit is always the same because the wage bill does not change over the cycle. There is thus no "credit boom" in good times. In contrast, deposits are high in good times and low in bad times. Hence, good times will be characterized by a low ratio of credit to deposits and bad times by a high ratio of credit to deposits. High powered money will move together with deposits.

A useful way of thinking about the banking sector's role over the cycle is as follows. When the bad times hit ( $\varepsilon$ increases), households reduce consumption and withdraw deposits from the banks. By itself, the lower volume of deposits reduces the bank's lending base. Banks, however, keep their total liabilities constant by switching to foreign borrowing. In effect, taking into account $(2.15),(2.20)$ can be rewritten as $z_{t}=-b_{t}^{b}+(1-\delta) d_{t}$. Hence, in bad times, $d$ falls and $b$ falls (i.e., banks' external debt increases). In terms of Figure 1, notice that, in the case of costless banking, the supply of credit does not depend on the level of deposits. Since the variability in deposits affects neither the supply nor the demand for credit, the equilibrium remains at point B. Intuitively, banks will satisfy the non-financial private sector's demand for credit regardless of the level of deposits, because the marginal cost of extending more credit is zero.

\subsection{Costly banking}

Consider now the case in which banking is costly. The following proposition yields the main result for this case. 
Proposition 1. Consider a perfect-foresight equilibrium path along which $\xi_{t}=\xi$, $i_{t}^{*}=i^{*}$, and $\delta_{t}=\delta$ for all $t \in[0, \infty)$. Suppose that for some $t=T, \varepsilon$ increases (falls). Then, $i^{\ell}-i$ also increases (falls). ${ }^{17}$

Proof. See Appendix.

This proposition says that during "bad times" (i.e., high inflation), the lending spread will also be high. With this piece of information, it is easy to characterize the response of all other relevant variables (see Figure 2). In equilibrium, the higher lending spread implies a higher ratio of credit to deposits, as follows from (2.16). Since firms face higher financial costs in bad times, the real wage will be lower (as follows from (2.12)). The lower real wage implies lower employment (more leisure), as indicated by (2.7). Given that, in equilibrium, both employment and the real wage will be lower, real credit will be lower as well (equation (2.9)). Since the ratio $z / d$ increases but $z$ falls, then $d$ must also fall. By the depositin-advance constraint (2.4), this implies that consumption falls. From (2.6), this means that $i-i^{d}$ increases. ${ }^{18}$

Intuitively, the temporary rise in $\varepsilon$ implies, through the interest parity condition (2.24), that the domestic nominal interest rate, $i$, is also temporarily higher. Since consumers must use demand deposits (which pay below-market interest rates) to consume, the effective price of consumption is temporarily higher. In response, consumers reduce consumption which, through the deposit-in-advance constraint, decreases the demand for deposits. Households thus withdraw deposits from the banking sector. How does the banking sector react to this withdrawal of deposits? Recall that, in the case of costless banking, banks simply substitute the lost deposits for foreign borrowing, leaving credit unchanged at point $\mathrm{B}$ in Figure 1. Suppose that banks proceeded in the same way when banking is costly; that is, suppose that banks kept unchanged the level of credit in response to the withdrawal of deposits. Then, since the fall in deposits shifts the supply of credit upwards in Figure 1, the economy would be at point $\mathrm{C}$, with a higher ratio of

${ }^{17}$ Strictly speaking, what is meant by the statement that a variable increases at time $T$ is that the path of the variable is discontinuous at $T$ and that its value at $T$ is higher than the left-hand limit (i.e., its value at $T^{-}$).

${ }^{18}$ Although, for simplicity, we did not introduce non-traded goods into the model, we would like to note the predictions of the model for the real exchange rate for the empirical exercise. If non-traded goods were introduced in the model, then good times (i.e., low interest rates) would be associated with real exchange rate appreciation. The simplest scenario would be to assume that there is an endowment of a non-traded good. Then, with separable utility, it would follow immediately that when the effective price of consumption falls the relative price of non-traded must increase to equilibrate supply and demand. 
credit to deposits and a higher lending spread, $i^{\ell}-i$. At point $\mathrm{C}$, however, there would be excess supply of credit. To restore credit market equilibrium, the lending spread needs to fall (relative to point $\mathrm{C}$ ) to stimulate credit demand and reduce supply. The new equilibrium is at point $D$, where credit is lower and the lending spread higher than in the initial equilibrium (point A). ${ }^{19}$

This case thus provides a powerful example of the role of the banking system in magnifying macroeconomic disturbances. In the absence of a costly banking system, the supply-side of the economy would be isolated from temporary stabilizations. With a costly banking system, periods of high rates of devaluation lead, through higher domestic nominal interest rates, to higher lending rates, lower credit, lower employment, and lower output. The credit crunch thus transforms the end of each stabilization cycle into a costly recession. ${ }^{20}$

\section{Reserve requirements as a countercyclical policy tool}

Since, by the interest parity condition, $i_{t}=i_{t}^{*}+\varepsilon_{t}$, fluctuations in the policycontrolled $\varepsilon_{t}$ have exactly the same effect as changes in $i_{t}^{*}$. Hence, all the results of the previous section apply to a path of $i_{t}^{*}$ that leads to the path of $i_{t}$ illustrated in Figure 2, Panel A. We take the fluctuations in $i_{t}^{*}$ as capturing the world business cycle, with periods of low $i_{t}^{*}$ corresponding to periods of capital inflows and periods of high $i_{t}^{*}$ to periods of capital outflows.

A recurrent theme in policy discussions is the use of reserve requirements during episodes of capital inflows or outflows. It has been argued (see, for example, Calvo, Leiderman, and Reinhart (1993)), that raising reserve requirements during episodes of capital inflows might help in preventing the resulting credit boom and the real exchange rate appreciation. In the aftermath of the Mexican crisis, Argentina provided a textbook example of the use of lower reserve requirements to inject liquidity into the banking system and mitigate the credit crunch. Our model provides a convenient conceptual framework to address this question. In fact, the model provides a strong theoretical case for the use of reserve requirements to insulate the economy from the world business cycle, as the following proposition

${ }^{19}$ Of course, in equilibrium, the level of deposits, the level of credit, and the lending spread are all determined simultaneously. We take the level of deposits as given to the credit market in Figure 1 for expository purposes.

${ }^{20}$ Notice that the model is thus able to explain the costly supply-side effects of temporary stabilization without relying on sticky prices (Calvo and Végh, 1993) or investment effects (Lahiri, 1995). 
Proposition 2. Consider a perfect-foresight equilibrium path along which $\xi_{t}=\xi$ and $\varepsilon_{t}=\varepsilon$ for all $t \in[0, \infty)$. Suppose that for some $t=T$, (i) $i^{*}$ increases (falls) and (ii) $\delta_{t}$ is reduced (increased) so that $\delta_{t} i_{t}$ does not change. Then, $i_{t}^{\ell}-i_{t}$ does not change at $T$.

Proof. See Appendix.

Since $i_{t}^{\ell}-i_{t}$ does not change at $T$, nothing else will, as can be easily checked. In particular, $i_{T}^{d}$ will also rise one-to-one with $i_{T}$. We have thus shown that if policymakers keep $\delta_{t} i_{t}$ constant over the cycle, then the economy will be completely insulated from fluctuations in world nominal interest rates. Such a policy ensures a constant path of consumption and employment. The intuition is simply that by keeping $\delta_{t} i_{t}$ constant, policymakers keep the effective price of consumption, $1+\alpha\left(i_{t}-i_{t}^{d}\right)$, constant over time. Recall that $i_{t}-i_{t}^{d}=\delta_{t} i_{t}+\xi \eta_{d}\left(1, \frac{d_{t}}{z_{t}}\right)$, which implies that banks will change the deposit spread only if their costs change over the cycle. Since the effective price of consumption does not vary over the cycle, neither does consumption or deposits.

This exercise thus provides support for a policy of raising reserve requirements in good times and lowering them in bad times. In practice, while policymakers often lower reserve requirements in bad times, they are sometimes reluctant to raise them in good times arguing that such a "tax" would lead to financial disintermediation. As the model makes clear, however, it is only if reserve requirements are raised in good times that they can perform an effective role in bad times. Hence, these cyclical considerations would argue for reserve requirements which are, on average, higher than that level which can be justified on regulatory or public finance grounds.

\section{Shocks to banking costs}

We now study the effects of shocks which hit directly the banking system. Specifically, we study the effects of a non-constant path of $\xi_{t}$. This shock can be interpreted as any domestic shock (such as changes in regulations or shocks to the underlying banking technology) or external shock (such as an international financial crisis) that makes it more costly for banks to perform their operations. The key formal result follows from the following proposition. 
Proposition 3. Consider a perfect-foresight equilibrium path along which $i_{t}^{*}=$ $i^{*}$ and $\delta_{t}=\delta$ for all $t \in[0, \infty)$. Suppose that for some $t=T, \xi$ increases (falls). Then, $i^{\ell}-i$ also increases (falls).

\section{Proof. See Appendix.}

A negative shock to the banking system thus leads to a higher lending spread. The higher financial costs result in a lower real wage (equation (2.12)), lower employment (equation (2.7)) and, hence, in a lower level of real credit in the economy (equation (2.9)). On the other hand, it can be shown that the deposit spread increases and consumption falls.

Intuitively, a higher $\xi$ hits directly banking costs. In terms of Figure 1, it shifts the supply of credit upward, because it increases the marginal cost of extending credit for a given ratio of credit to deposits. To clear the credit market, the lending spread must increase, which reduces the level of credit to firms and leads to lower employment and output. On the deposit side, the higher $\xi$ increases the marginal cost of taking deposits for a given ratio of credit to deposits. This leads banks to reduce the rate on deposits paid to consumers, which increases the effective price of consumption. In response, households reduce consumption. In sum, the negative shock to banks spreads throughout the economy through higher lending rates (which depress employment and production) and lower deposits rates (which reduce consumption).

\subsection{Reserve requirements}

The question is now whether by lowering reserve requirements in bad times, policymakers can fully insulate the economy. We will show that this is not possible.

Suppose that, faced with a negative shock to the banks (i.e., a higher $\xi$ ), policymakers sought to keep the lending spread $\left(i^{\ell}-i\right)$ constant to insulate production and employment. Since $i_{t}^{\ell}-i=\xi_{t} \eta_{z}\left(\frac{z_{t}}{d_{t}}, 1\right)$, such an objective can only be achieved by lowering reserve requirements and thus lowering the ratio $z / d$ to the point where the fall in the marginal cost of extending credit exactly offsets the rise in $\xi_{t}$. An unchanged lending rate implies that the real wage and employment do not change. Hence, real credit does not change. This implies that the lower $z / d$ must be achieved by deposits (and thus consumption) going up. In terms of Figure 1, policymakers are shifting downward the supply of credit by inducing consumers to hold more deposits in good times, so that the equilibrium in the credit market remains at point A. Policymakers can therefore insulate the supply side of the economy only by inducing higher consumption. The other side of the 
coin is that when a positive shock hits the banking system, policymakers would have to raise reserve requirements and induce a contraction in consumption to keep the level of credit constant.

Now suppose that, faced with a negative shock, policymakers wanted to keep the deposit rate, and thus consumption, constant. If consumption remains unchanged, so do deposits. In the credit market, however, the supply of credit shifts upward due to the negative shocks to bank costs. In the new equilibrium (at a point like D), real credit is lower and so is employment and production. Policymakers do not succeed in insulating the supply side if they manipulate reserve requirement so that consumption does not change over the cycle.

In conclusion, since a higher $\xi$ hits directly the banking system and its effects reverberate to both the supply and the demand side of the economy, policymakers cannot change reserve requirements so as to eliminate the cyclical variations in both employment and consumption induced by shocks that affect the banking system.

\section{Empirical analysis}

This section uses monthly data for Chile and Mexico to evaluate the main implications of the model. In particular, we inquire the extent to which different shocks to the banking sector affect some key macroeconomic variables. We concentrate on four types of shocks: (a) shocks to international interest rates; (b) shocks to the rate of devaluation; (c) shocks to domestic lending interest rates; and $(\mathrm{d})$ shocks to the spread between lending and deposit rates. We interpret the shock to the spread as proxying the theoretical shock to the banking sector $(\xi)$ in our model. While world interest rates are truly exogenous, the rate of devaluation, domestic interest rates, and interest rate spreads are exogenous to individual banks, but endogenous to the economy as a whole. All of our data were obtained from the IMF's International Financial Statistics. We begin the section with a brief account of the Chilean and Mexican experiments with exchange rate based stabilization.

\subsection{An overview of the Chilean and Mexican experiences}

The Chilean reform program was initiated in 1975, ten years prior to the launching of the Mexican reforms. Nevertheless, both programs shared a number of features: (a) a drastic opening of the economy; (b) ambitious privatization and deregula- 
tion; and (c) stabilization plans based on a predetermined, nominal exchange-rate anchor, supported by (largely) restrictive fiscal and monetary policies. Table 1 contains a brief comparison of the policies undertaken in both countries. Table 2, on the other hand, provides a detailed comparison of the nominal exchange rate policies followed in both countries. ${ }^{21}$

As their reforms proceeded and became consolidated, both Chile and Mexico were subject to very large capital inflows which helped finance increasingly large current account deficits. In Chile the current account deficit exceeded 12 percent of GDP in 1981, while in Mexico it surpassed 7 percent of GDP both in 1992 and 1993.

In both counties capital inflows were intermediated by the recently privatized banking systems. As Figure 3 shows, in both countries credit to the private sector increased at very rapid rates, helping fuel major consumption booms. Between 1977 and 1981 private consumption increased in Chile at an annual real rate of 45 percent! In Mexico, on the other hand, private consumption increased at the lower, but still astonishing, annual real rate of 32 percent between 1987 and 1994 . Figure 3 also shows that, in both countries, credit collapsed following the crises.

In both countries the stabilization programs succeeded in bringing inflation down. In the process, however, the real exchange rate appreciated significantly. An important question, both at the time of the programs and in post-mortem analyses, has been whether these real appreciations were justified by "fundamentals" - and especially by massive capital inflows - as the authorities in both countries argued, or whether, as the critics pointed out, they represented a disequilibrium situation. ${ }^{22}$

Another important similarity between the Chilean and Mexican experiences has to do with the external environment. Both countries were subject to large exogenous shocks. Both of them faced large increases in international interest rates as well as political upheaval. For instance, long term U.S. bond rates increased by 600 basis points between July 1979 - when Chile fixed its exchange rate - and July of 1981. Likewise, the U.S. long term rate increased by almost 300 basis points between July 1993 and July 1994. At the end of the road, in both countries the combination of overvaluation, exogenous shocks, bankruptcies and

${ }^{21}$ On the Chilean reforms, see Harberger (1985), Edwards and Edwards (1991), and Bosworth, Dornbusch, and Laban (1994). On the Mexican experience, see Aspe (1995), Dornbusch and Werner (1994), and Calvo and Mendoza (1995).

${ }^{22}$ For accounts of the controversies that emerged during the implementation of both programs, see Edwards and Edwards (1991) and Dornbusch, Goldfajn, and Valdez (1996). 
bank failures proved to be too much. The pegged exchange rate was abandoned, the banking sector entered into a deep crisis, unemployment soared, and output declined.

\subsection{Preview of the data}

In this subsection we take a preliminary look at the data. According to our model, shocks to both international interest rates (an increase in $i^{*}$ ) and to the rate of devaluation (an increase in $\varepsilon$ ) will generate the following effects: an increase in domestic interest rates; an output decline; a drop in deposits and credit; a decline in the ratio of deposits to credit; an increase in the interest rate spread; and a real exchange rate depreciation. ${ }^{23}$ Naturally, since a higher $i^{*}$ and a higher $\varepsilon$ both lead to a higher domestic interest rate $(i)$ through the interest parity condition (recall equation (2.24)), a shock to $i$ will have the same effects on the key variables.

Figure 4 contains monthly data on U.S. nominal interest rates (USIR61) and some key macroeconomic variables for Chile for the period 1979-1983. In each diagram the date of Chile's currency crisis is indicated with a vertical line. The variables are defined as follows: SPREAD refers to the spread between lending and borrowing interest rates; PR66EYSA is the seasonally-adjusted index of industrial production; IR60P is the nominal lending interest rate: ERREC is the effective real exchange rate as defined by the IMF (an increase in the index denotes appreciation); and DEP_DCRE is the ratio of private sector deposits to domestic credit. In Figure 5 data for Mexico are presented. There are two changes in notation with respect to Chile. The Mexican lending interest rate is denoted by IR60N; and RER is an index of Mexico's bilateral real exchange rate with respect to the United States (where, again, an increase in the index denotes a real appreciation).

As can be seen from these figures, in both countries the evolution of macroeconomic variables is broadly consistent with the theoretical model developed in the preceding sections. As the first panel in each figure shows, the Chilean and Mexican exchange rate crises were preceded by significant increases in foreign interest rates. In the Chilean episode, higher U.S. interest rates were translated into more volatile and higher average domestic lending rates. Between the second semester of 1980 and the first semester of 1982 the nominal lending interest rate

${ }^{23}$ There are other implications which, unfortunately, cannot be tested due to the lack of data. In particular, we cannot test the implications of the model for changes in reserve requirements (see Loungani and Rush (1995) for such evidence for the United States). 
in Chile increased by more than one thousand basis points; during the same period the annualized rate of inflation declined from 16 to 6 percent. That is, in a period of 18 months the average real interest rate increased by 2,000 basis points! In Mexico, nominal lending interest rates increased 400 basis points between the first and last quarters of 1994.

The Chilean data in Figure 4 show that, as predicted by the model, output experienced a significant decline during the period of rising world interest rates. In Mexico, on the other hand, the decline in industrial production took place with a lag and only became significant in 1995, after the currency crisis. Also, as indicated by the model, in both countries there was a marked decline in the ratio of private sector deposits to domestic credit. This drop, however, was more pronounced in the case of Chile. An interesting fact, not shown graphically due to space considerations, is that in Chile both demand and time deposits declined sharply during 1981-82. In Mexico, on the other hand, while demand deposits declined drastically, time deposits - mostly dollar-denominated time deposits increased somewhat. This is a sign of the important role of currency substitution in situations of currency uncertainty. Moreover, this shows that when there is a widespread availability of foreign currency denominated deposits the dynamics of adjustment can differ significant from the case in which these deposits are restricted. As the second panel in each figure shows, in both countries the interest rate spread increased at approximately the same time as world interest rates rose. Once again, however, the comovement of both variables appears to be more pronounced in Chile than in Mexico. Finally, in both countries the real exchange rate appreciated in the period preceding the currency crisis, only to plunge drastically after the devaluation. In Chile the real exchange rate maintained a highly depreciated level for years after the crisis. In Mexico, on the other hand, it is still too early to know whether a (real) weakened currency will be maintained into the future.

Generally speaking, then, a preliminary analysis of the raw data suggests that in both the Chilean and Mexican episodes economic variables roughly behaved in the way predicted by the model. In particular, Figures 4 and 5 provide broad (and preliminary) support to the idea that in an economy with a predetermined nominal exchange rate, world interest rate shocks affect the deposits/credit ratio, interest rate spreads, and output.

Figures 4 and 5 also show, however, that in practice the relationship between these different variables is neither mechanical nor instantaneous. In fact, a careful analysis of these figures indicates the presence of nontrivial lags in the (possi- 
ble) response of domestic macroeconomic variables to foreign interest rate disturbances. In the rest of this section we use dynamic VAR analysis to examine the dynamic response of the key variables to shocks to world interest rates and to the nominal rate of devaluation. The analysis is in two stages: we first use VARs to analyze the impact of a one standard deviation innovation to $i^{*}$ and $\varepsilon$ on domestic interest rates. In the second stage we inquire how shocks to domestic interest rates - $i$ in our model - affect output, the deposit ratio, the interest rate spread, and the real exchange rate. Before presenting the VAR results, however, we discuss briefly the time series properties of the different macroeconomic variables.

\subsection{Time series properties and Granger causality}

Table 3 contains the results from Phillips-Perron stationarity tests for monthly time series in Chile and Mexico. In order to capture the longer term properties of these series, a sample that went well beyond the period surrounding the crises was used. In Chile the analysis deals with monthly data for 1979-1993. In Mexico the analysis concentrates on the period 1986-1995.

As Table 3 shows, the results are quite similar across countries. The unit root null hypothesis cannot be rejected at conventional levels for real deposits, real credit, the deposit-credit ratio, and the industrial production index. For all these variables, on the other hand, the once-differenced series appear to be stationary. In the two countries, lending interest rates, interest rate spreads and the real exchange rate appear to be stationary in levels. Moreover, a Phillips-Perron test for U.S. long term interest rates indicates that the null hypothesis of a unit root can be rejected (marginally) at the conventional levels. In light of these results, and in order to induce stationarity, we removed the trend from the different series using a Hodrick- Prescott filter. ${ }^{24}$ This allows us, in the subsection that follows on dynamic VARs, to work with the cyclical component of the data.

In order to gain additional insights into the dynamic process, Granger-causality tests were performed for both countries. The results obtained are summarized in Table 4, and are largely supportive of the "story" suggested by the theoretical model. As can be seen, the null hypothesis that interest rates (domestic and U.S.) Granger-cause industrial production cannot be rejected at conventional levels; reverse Granger-causality, on the other hand, is rejected. The results are

${ }^{24}$ As Baxter and King (1995) have convincingly argued, it is preferable to use a "band-pass filter" to obtain cyclical components. In our case, unfortunately, the rather short period for which data are available makes this preferred procedure more difficult to use. 
also consistent with the deposit-in-advance constraint, and with the notion that changes in interest rate spreads precede changes in real economic activity. The only result not consistent with the predictions of the model refers to industrial production and the deposit-credit ratio in Mexico. Contrary to what the theory indicates, the hypothesis that real output - proxied by industrial production Granger-causes this ratio cannot be rejected at conventional levels. Moreover, the null hypothesis that the deposit-credit ratio causes real output is rejected at conventional levels.

\subsection{Vector autoregression analysis}

We now use vector autoregression analysis to investigate the dynamic response of the key variables to a series of exogenous shocks. ${ }^{25}$ In the estimation (up to) 7 lags were used. In Chile the monthly data set went from 1979 through 1993, while in Mexico the sample covered 1988 through 1995. In order to organize the discussion, and as pointed out above, the analysis was carried out in two stages. We first analyzed the way in which shocks to world interest rates and to the nominal rate of devaluation affect domestic interest rates. In the second stage we analyzed how shocks to domestic interest rates and to the interest rate spread affect output, the deposits to credit ratio, the spread itself and the real exchange rate. In this analysis we interpret changes in the spread as proxying our theoretical shock to the banking system (the shock to $\xi$ ). The following notation is used: PROCY is seasonally-adjusted industrial production; SPREADCY is the spread between lending and deposit rates, IR60PCY and IR60NCY are domestic lending interest rates, USIR60BCY and USIR61CY are U.S. interest rates, DEV is the nominal rate of devaluation, and ERREC and ERERCY are indexes of the real exchange rate. Figures 6 and $6 \mathrm{~A}$ contain the impulse response functions of domestic interest rates. They show that, in Chile and Mexico, shocks to world interest rates and to the rate of devaluation are translated into higher domestic nominal exchange rates. This is, indeed, what the model suggests and what would be expected in countries with a (semi) open capital account. Interestingly enough, in both countries domestic interest rates appear to be more sensitive to devaluation shocks than to world interest rate shocks. The results for Mexico suggest that while a devaluation is immediately translated into a higher domestic interest rate, a higher U.S. interest rate impacts the domestic rate only after one

${ }^{25} \mathrm{As}$ is customary in these type of analyzes, we investigated the sensitivity of the results to the ordering of the variables. The main thrust of the results presented here was not affected. 
month. In Chile the dynamic response is quite interesting, suggesting that while the effect of a devaluation shock dies off after eight months, that of a world interest rate shock lasts for over 10 months.

According to the model, it is the increase in the domestic interest rate (i.e., the variable $i$ ) - as a result of shocks to either $i^{*}$ or to $\varepsilon$ - what impacts on output, deposits, and the other key variables. Figures 7 and 8 contain the impulse response functions of output (PROCY), interest rate spreads (SPREADCY), the deposits to credit ratio (DE_DCY) and the real exchange rate to shocks in domestic interest rates and the spread. As can be seen from the first panel in Figures 7 and 8 , and as predicted by the model, both shocks have a negative effect on the level of economic activity. The relative magnitude and the time pattern of the response are different across countries. In both countries, however, the shock to the interest rate has the greatest impact on economic activity, reaching its maximum (negative effect) after five months in Chile and after four months in Mexico. Also, as predicted by the model, the interest rate shock results in an increase in the spread. While in Chile this effect dies off after six months, in Mexico it lasts for only four months

The third panel in Figure 7 shows that in Chile, and as predicted by the model, interest rate shocks and shocks to the banking sector — proxied by a shock to the spread - have a negative effect on the deposits to credit ratio. The effect is more pronounced in response to a spread shock, and lasts for more than 10 months. The response of the deposits to credit ratio in Mexico is presented in the third panel of Figure 8. Again, and as predicted by the model, these shocks generate an immediate decline in the deposit ratio. In Mexico, however, the response is different than in Chile. In fact, in Mexico, the deposits to credit ratio barely declines in response to the interest rate shock, and after 4 months it starts to increase. In Mexico, as in Chile, however, the deposits to credit ratio responds negatively to the spread shock.

The last panel in Figures 7 and 8 captures the response of the real exchange rate to the two shocks. Here the results are largely consistent with the model. In both countries the real exchange rate responds as predicted - it depreciates in response to the two shocks. In Chile, however, the index of the (effective) real exchange rate barely responds to the domestic interest rate shock.

\section{Conclusions}

An examination of the Chilean and Mexican experiences leading up to the crisis of 1982 and 1994, respectively, suggests that the banking sector played a prominent 
role in fueling the expansionary phase and, later on, in propagating the crisis. The same phenomenon has been observed in many other boom-bust episodes in Latin America and elsewhere. In fact - and rightly so - policy discussions often place a great deal of emphasis on the interaction between the banking sector, shocks, and macroeconomic policy.

For all its practical relevance, the role of the banking system has been virtually ignored in most formal work dealing with these issues. This paper develops a simple, general equilibrium, optimizing model of a small open economy which includes a non-trivial role for the banking system. In the tradition of the credit channel literature, the model assumes that firms need bank credit to pay the wage bill. Running a bank is a costly activity: the larger is the bank (as measured by the level of credit and deposits), the higher are the costs. We show how the simple (and realistic) assumption that banking is a costly activity is enough to alter dramatically the picture that would obtain otherwise. Since, at the margin, it is costly for banks to extend more credit and to take more deposits, shocks to consumption and deposits are transmitted to the supply-side through a rise in lending rates and a credit contraction. The presence of a costly banking system is therefore enough to amplify the world business cycle. In good times, the increased availability of credit fuels a production boom. In bad times, production and employment contract. Econometric evidence for Chile and Mexico broadly supports the transmission channels and the main implications of the model.

We view this simple model as a first step in developing simple but rigorous macro-models of open economies that include a meaningful role for banks. This task is all the more urgent in a world of increasing capital mobility where huge amounts of financial capital may flow into or out of a country in a matter of minutes. The model is not aimed at "explaining" the existence of banks or assessing the optimal level of regulation or capital (in which case uncertainty should figure prominently in the analysis). Rather, the idea is to take the banking system as a given and focus on its role in the transmission mechanism and the resulting policy implications.

Within this framework, there are several avenues worth pursuing. First, it would be important to understand the role that a devaluation would have in this banking model. As the model now stands, an unanticipated increase in the level of the exchange rate would simply generate an equiproportional rise in prices. (Anticipated devaluations are simply not feasible in a world of perfect certainty and perfect capital mobility.) Hence, one would need to introduce some nominal rigidity that would make a devaluation a non-trivial exercise. 
Second, given the widespread dollarization of many banking systems in Latin America (see, for example, Savastano (1995)), the role of foreign-currency deposits in the banking system should be examined. In fact, for all the literature that it has generated (see Calvo and Végh (1996) for a critical review), it is difficult to escape the feeling that the most critical aspect of dollarization (as a base for the creation of Mex-dollar or Argen-dollars) may yet to be well-understood. Finally, the government's role in providing credit to the banking sector in moments of distress appears as an important item in the agenda. This policy was particularly apparent in the case of Chile (see Edwards and Edwards (1991)).

\section{References}

[1] Aspe, Pedro,1995, Economic transformation: the Mexican way, Cambridge, MA: MIT Press.

[2] Bernanke, Ben. S., and Alan Blinder, 1988, Credit, money, and aggregate demand, American Economic Review 78, 435-439.

[3] Bernanke, Ben. S., and Alan Blinder, 1992, The Federal Funds rate and the channels of monetary transmission, American Economic Review 82, 901-921.

[4] Bernanke, Ben S. and Mark Gertler, 1995, Inside the black box: the credit channel of monetary policy transmission, The Journal of Economic Perspectives $9,27-48$.

[5] Baxter, Marianne and Robert King, 1995, Measuring business cycles: approximate time-band filters for economic time series, NBER Working Paper 5022 .

[6] Bosworth, Barry P., Rudiger Dornbusch and Raul Laban, eds., 1994, The Chilean economy: policy lessons and challenges, Washington, D.C.: The Brookings Institution.

[7] Bruno, Michael, 1979, Stabilization and stagflation in a semi-industrialized economy, in Rudiger Dornbusch and Jacob Frenkel, eds., International economic policy: theory and evidence, Baltimore: the Johns Hopkins University Press.

[8] Bruno, Michael, 1993, Crisis, stabilization and economic reform: therapy by consensus, Oxford: Clarendon Press. 
[9] Calvo, Guillermo A., 1995, Varieties of capital-market crises, Paper presented at the 8th Annual Inter-American Seminar on Economics, NBER and FEDESARROLLO, Bogota, Colombia.

[10] Calvo, Guillermo, Leonardo Leiderman, and Carmen Reinhart, 1993, Capital inflows and real exchange rate appreciation in Latin America: the role of external factors, IMF Staff Papers 40, 108-151.

[11] Calvo, Guillermo, and Enrique Mendoza, 1995, Reflections on Mexico's balance-of- payments crisis: a chronicle of a death foretold, mimeo, Center of International Economics, University of Maryland.

[12] Calvo, Guillermo and Carlos A. Végh, 1993, Exchange rate-based under imperfect credibility, in Helmut Frisch and Andreas Worgotter, eds., Open economy macroeconomics, London: McMillan Press, 3-28.

[13] Calvo, Guillermo and Carlos A. Végh, 1996, From currency substitution to dollarization and beyond: analytical and policy issues, in G. Calvo, Money, exchange rates, and output, Cambridge, Mass.: MIT Press, 153-175.

[14] Catena, Marcelo, 1996, Banking crises and monetary policy in Argentina, mimeo, UCLA.

[15] Diaz-Gimenez, Javier, Edward C. Prescott, Terry Fitzgerald, and Fernando Alvarez, 1992, Banking in computable general equilibrium economies, Journal of Economic Dynamics and Control 16, 533-559.

[16] Dornbusch, Rudiger, Ilan Goldfajn and Rodrigo Valdes, 1996 (forthcoming), Currency crises and collapse, Brookings Papers on Economic Activity.

[17] Dornbusch, Rudiger and Alejandro Werner, 1994, Mexico: Stabilization, Reform and No Growth, Brookings Papers on Economic Activity 1: 253-315.

[18] Edwards, Sebastian, 1993, Exchange rates as nominal anchors, Weltwirtschaftliches Archiv 129, 1 - 32.

[19] Edwards, Sebastian, 1995, Crisis and reform in Latin America: from despair to hope. New York: Oxford University Press.

[20] Edwards, Sebastian and Alejandra Edwards, 1991, Monetarism and liberalization: the Chilean experiment. Chicago and London: University of Chicago Press, Second Edition. 
[21] Feenstra, Robert, 1985, Anticipated devaluations, currency flight, and direct trade controls in a monetary economy, American Economic Review 75, 386401.

[22] Fischer, Stanley, 1983, A framework for monetary and banking analysis, Economic Journal (March), 1-16.

[23] Guidotti, P., "Debt, monetary, and banking policy in emerging markets: reflections from the Tequila effect," mimeo, Ministry of Finance, Argentina.

[24] Harberger, Arnold C., 1985, Observations on the Chilean economy, 19731983, Economic Development and Cultural Change 33, 451-62.

[25] Kaminsky, Graciela, and Carmen M. Reinhart, 1995, The twin crises: the causes of banking and balance of payments problems, mimeo, Board of Governors and University of Maryland.

[26] King, Robert G., and Ross Levine, 1993, Finance and growth: Schumpeter might be right, Quarterly Journal of Economics 108, 717-737.

[27] Lahiri, Amartya, 1995, Exchange rate based stabilization under real frictions: the role of endogenous labor supply, mimeo, UCLA.

[28] Loungani, Prakash, and Mark Rush, 1995, The effect of changes in reserve requirements on investment and GNP, Journal of Money, Credit and Banking $27,511-526$.

[29] Lucas, Robert E., Jr., 1993, On the welfare costs of inflation, mimeo, University of Chicago.

[30] Mishkin, Frederic S., 1995, The Mexican financial crisis of 1994-1995: an asymmetric information analysis, mimeo, Federal Reserve Bank of New York.

[31] Obstfeld, Maurice, 1995, International currency experience: new lessons and lessons relearned." Brookings Papers on Economic Activity (1): 119 - 220.

[32] Rebelo, Sergio and Carlos A. Végh, 1995, Real effects of exchange rate-based stabilizations: an analysis of competing theories, NBER Macroeconomics Annual 1995, 125-174. 
[33] Rojas-Suarez, Liliana, and Steven R. Weisbrod, 1994, Financial market fragilities in Latin America: from banking crisis resolution to current policy challenges, Working Paper 94/117, IMF.

[34] Roldos, Jorge, 1993, "On credible disinflation," Working paper 93/90, IMF.

[35] Sachs, Jeffrey, Aaron Tornell, and Andres Velasco, 1995, Lessons from Mexico, mimeo, Harvard University.

[36] Savastano, Miguel, Dollarization in Latin America, Working paper (IMF), 1995.

[37] Végh, Carlos A., 1992, "Stopping high inflation: an analytical overview," IMF Staff Papers 39, 629-705.

\section{Appendix}

Proof of Proposition 1. The proof proceeds by contradiction.

(i) Suppose that when $\varepsilon$ increases at $T$ (that is, $\varepsilon_{T}>\varepsilon_{T^{-}}$), $i^{\ell}-i$ remains unchanged at $T$ (that is, $i_{T}^{\ell}-i_{T}=i_{T^{-}}^{\ell}-i_{T^{-}}$). This implies, by (2.26), that $x_{T}$ does not change and, by (2.16), that $z_{T} / d_{T}$ does not change. Rewrite equation (2.17) as $i_{T}-i_{T}^{d}=\delta i_{T}+\xi \eta_{d}\left(1, \frac{d_{T}}{z_{T}}\right)$. Since $i_{T}$ increases (through the interest parity condition (2.24)) and $\dot{z}_{T} / d_{T}$ does not change, $i_{T}-i_{T}^{d}$ increases. Then, by (2.6), $c_{T}$ falls. Since $z_{T} / d_{T}=\alpha \gamma\left(1-x_{T}\right) / c_{T}\left[1+\gamma\left(i_{T}^{\ell}-i_{T}\right)\right]$, the fall in $c_{T}$ implies that $z_{T} / d_{T}$ increases, which is a contradiction.

(ii) Suppose that when $\varepsilon_{T}$ increases, $i_{T}^{\ell}-i_{T}$ falls. This implies, by (2.26), that $x_{T}$ falls and, by (2.16), that $z_{T} / d_{T}$ falls (i.e., $d_{T} / z_{T}$ increases). Since, from (2.17), $i_{T}-i_{T}^{d}=\delta i_{T}+\xi \eta_{d}\left(1, \frac{d_{T}}{z_{T}}\right)$, the rise in $d_{T} / z_{T}$ and in $i_{T}$ implies that $i_{T}-i_{T}^{d}$ increases. Then, by (2.6), $c_{T}$ falls. Since $z_{T} / d_{T}=\alpha \gamma\left(1-x_{T}\right) /\left[c_{T}\left[1+\gamma\left(i_{T}^{\ell}-i_{T}\right)\right]\right]$, the fall in $c_{T}, i_{T}^{\ell}-i_{T}$, and $x_{T}$ implies that $z_{T} / d_{T}$ increases, which is a contradiction. QED

Proof of Proposition 2. The proof proceeds by contradiction.

(i) Suppose that $i^{\ell}-i$ increases at $T$. This implies, by (2.26), that $x_{T}$ increases and, by (2.16), that $z_{T} / d_{T}$ increases. Since $i_{T}-i_{T}^{d}=\delta i_{T}+\xi \eta_{d}\left(1, \frac{d_{T}}{z_{T}}\right)$, the rise in $z_{T} / d_{T}$ implies that $i_{T}-i_{T}^{d}$ falls. Hence, by (2.6), $c_{T}$ increases which implies, by (2.4), that $d_{T}$ increases. Since both $d_{T}$ and $z_{T} / d_{T}$ increase, $z_{T}$ must increase. This contradicts the fact that since labor falls (because $x_{T}$ increases) and the real 
wage falls (from (2.12)), the credit-in-advance constraint (2.9) indicates that $z_{T}$ must fall.

(ii) Suppose that $i^{\ell}-i$ falls at $T$. This implies, by (2.26), that $x_{T}$ falls and, by (2.16), that $z_{T} / d_{T}$ falls. Since $i_{T}-i_{T}^{d}=\delta i_{T}+\xi \eta_{d}\left(1, \frac{d_{T}}{z_{T}}\right)$, the fall in $z_{T} / d_{T}$ implies that $i_{T}-i_{T}^{d}$ rises. Hence, by (2.6), $c_{T}$ falls which implies, by (2.4), that $d_{T}$ falls. Since both $d_{T}$ and $z_{T} / d_{T}$ fall, $z_{T}$ must fall. This contradicts the fact that since labor increases (because $x_{T}$ falls) and the real wage increases (from (2.12)), the credit-in-advance constraint (2.9) indicates that $z_{T}$ must increase. QED

Proof of Proposition 3. The proof proceeds by contradiction.

(i) Suppose that $i^{\ell}-i$ remains unchanged at $T$. By (2.16), this implies that $z_{T} / d_{T}$ falls. Then, by (2.17), $i_{T}-i_{T}^{d}$ increases, which implies, by (2.6), that $c_{T}$ falls. Then, by (2.4), $d_{T}$ falls. Also, since $i_{T}^{\ell}-i_{T}$ does not change, labor does not change either (from (2.7) and (2.23)), which implies, by (2.9), that $z_{T}$ does not change. Since $d_{T}$ falls and $z_{T}$ does not change, $z_{T} / d_{T}$ increases, which is a contradiction.

(ii) Suppose that $i^{\ell}-i$ falls at $T$. By (2.16), this implies that $z_{T} / d_{T}$ falls. Then, by (2.17), $i_{T}-i_{T}^{d}$ increases, which implies, by (2.6), that $c_{T}$ falls. Then, by $(2.4), d_{T}$ falls. Also, since $i_{T}^{\ell}-i_{T}$ falls, labor increases (from (2.7) and (2.23)), which implies, by (2.9), that $z_{T}$ increases. Since $d_{T}$ falls and $z_{T}$ increases, $z_{T} / d_{T}$ increases, which is a contradiction. QED 
Figure 1. Credit Market Equilibrium

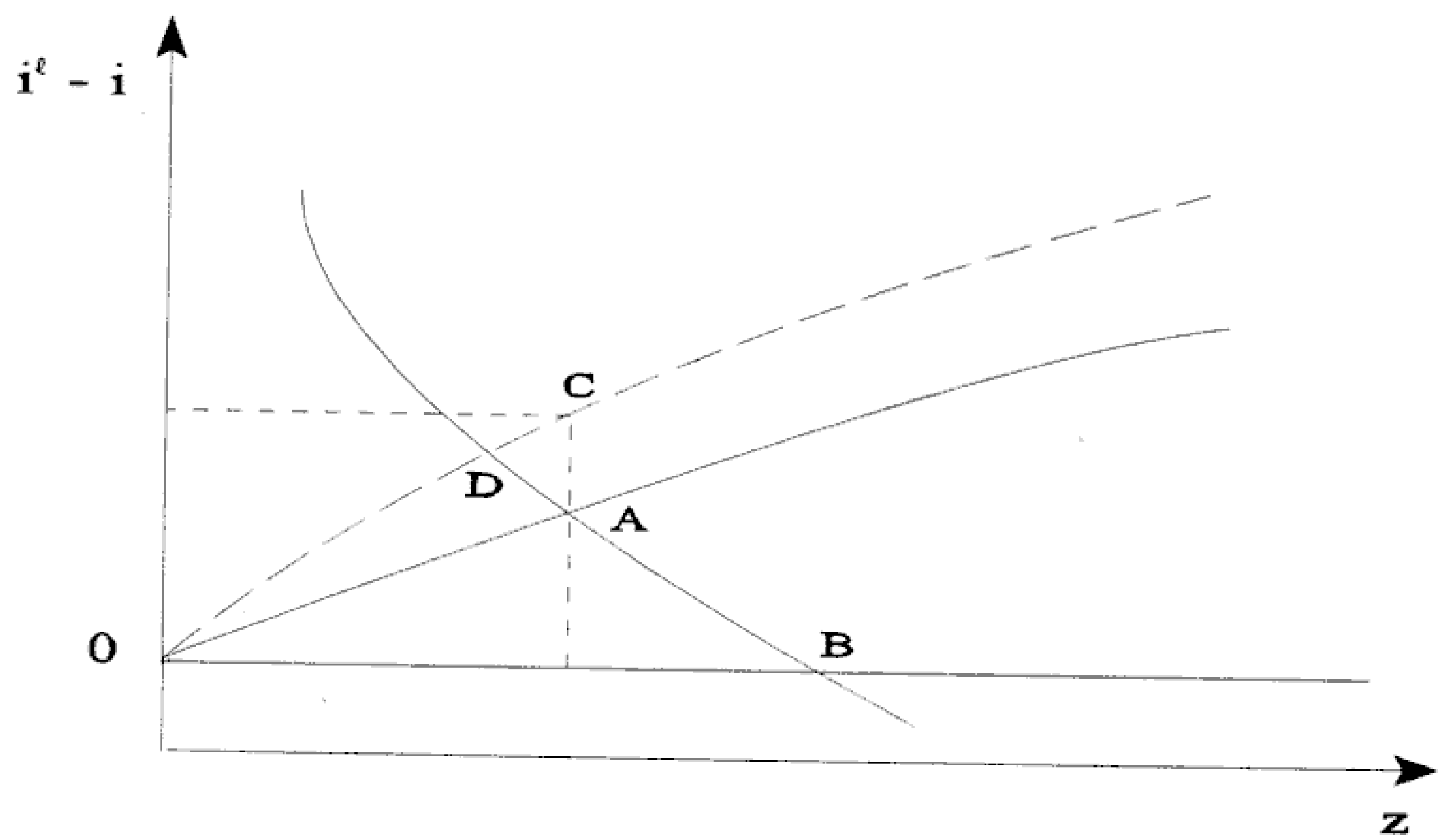


Figure 2. Shocks to Domestic Interest Rates

A. Domestic interest rate

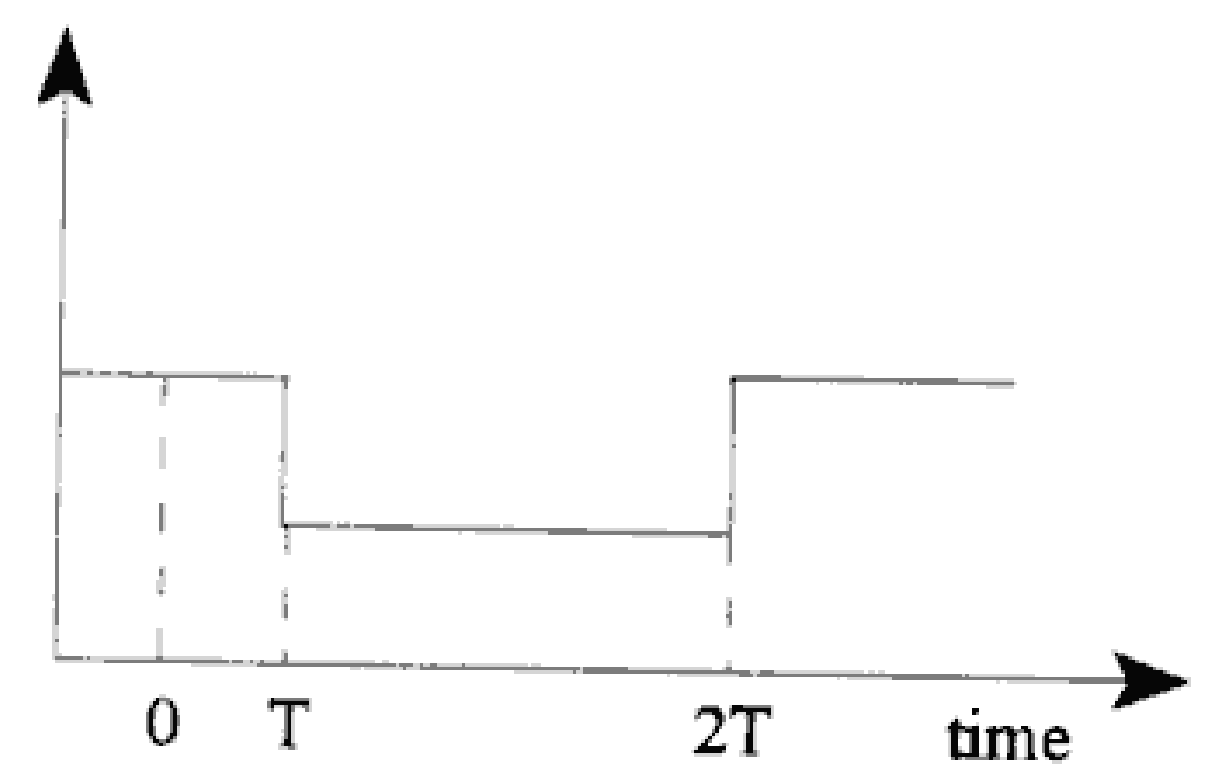

C. Output

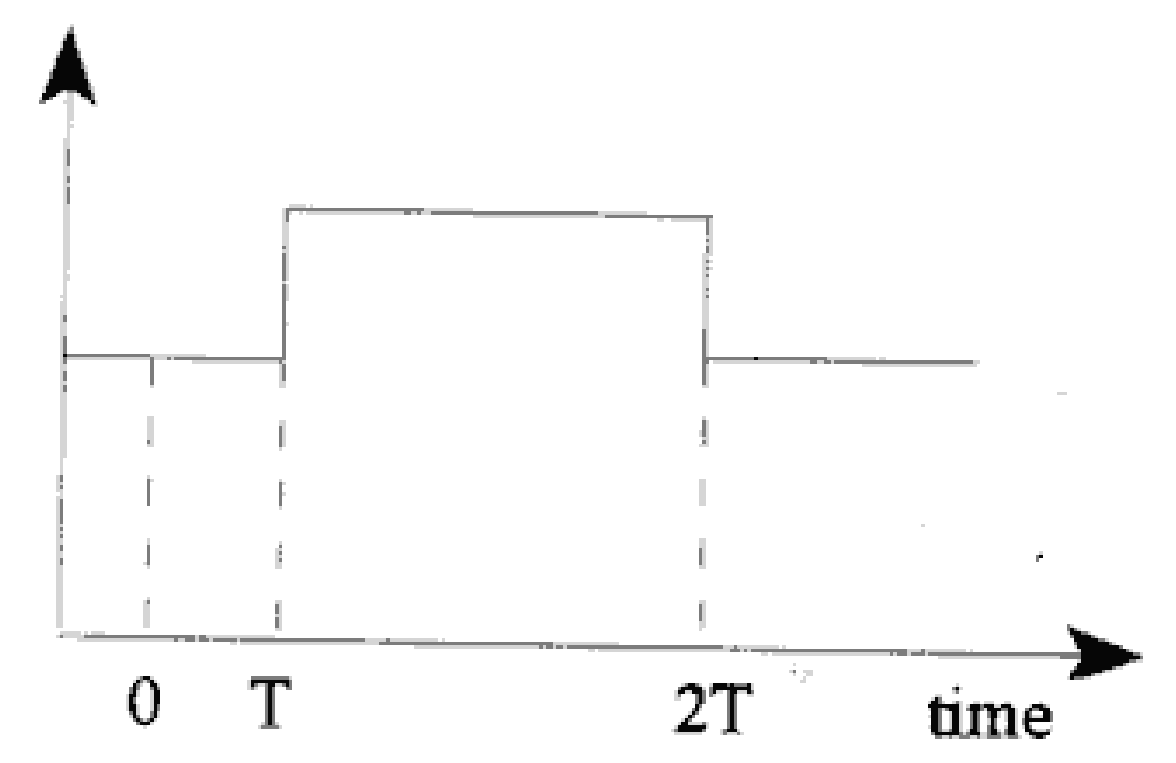

E. De posits to credit ratio

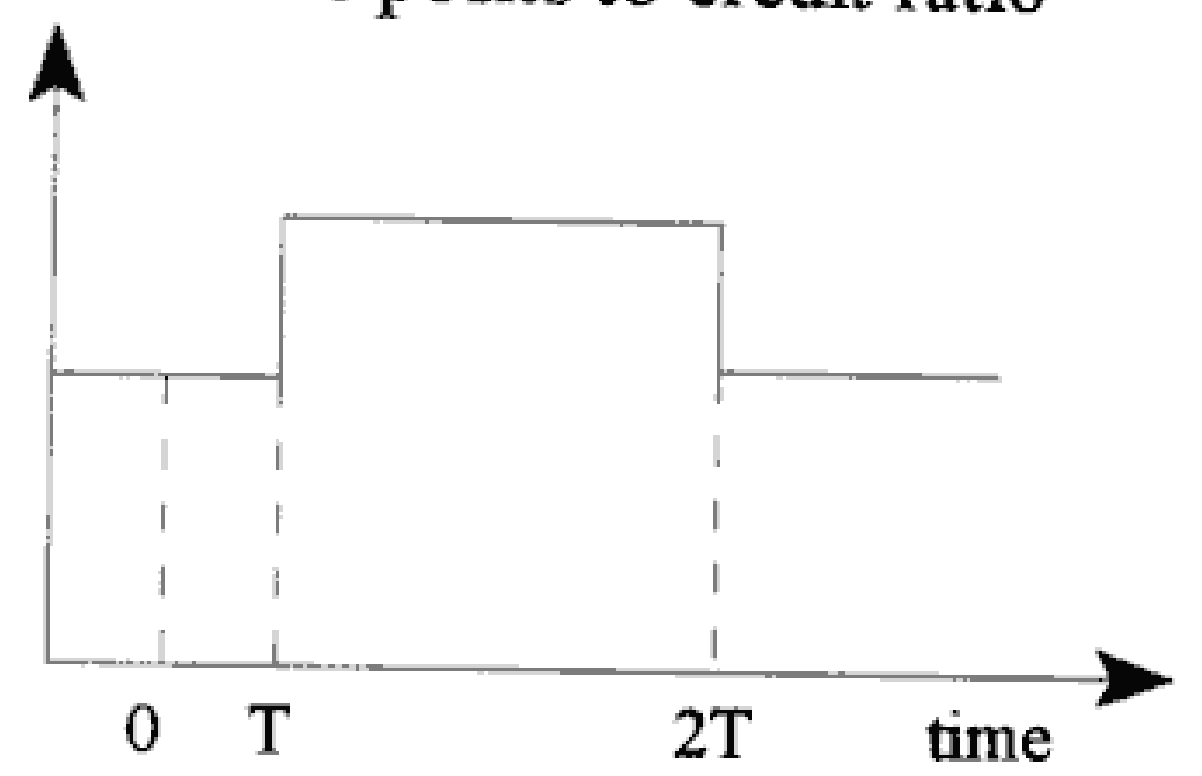

B. Consumption

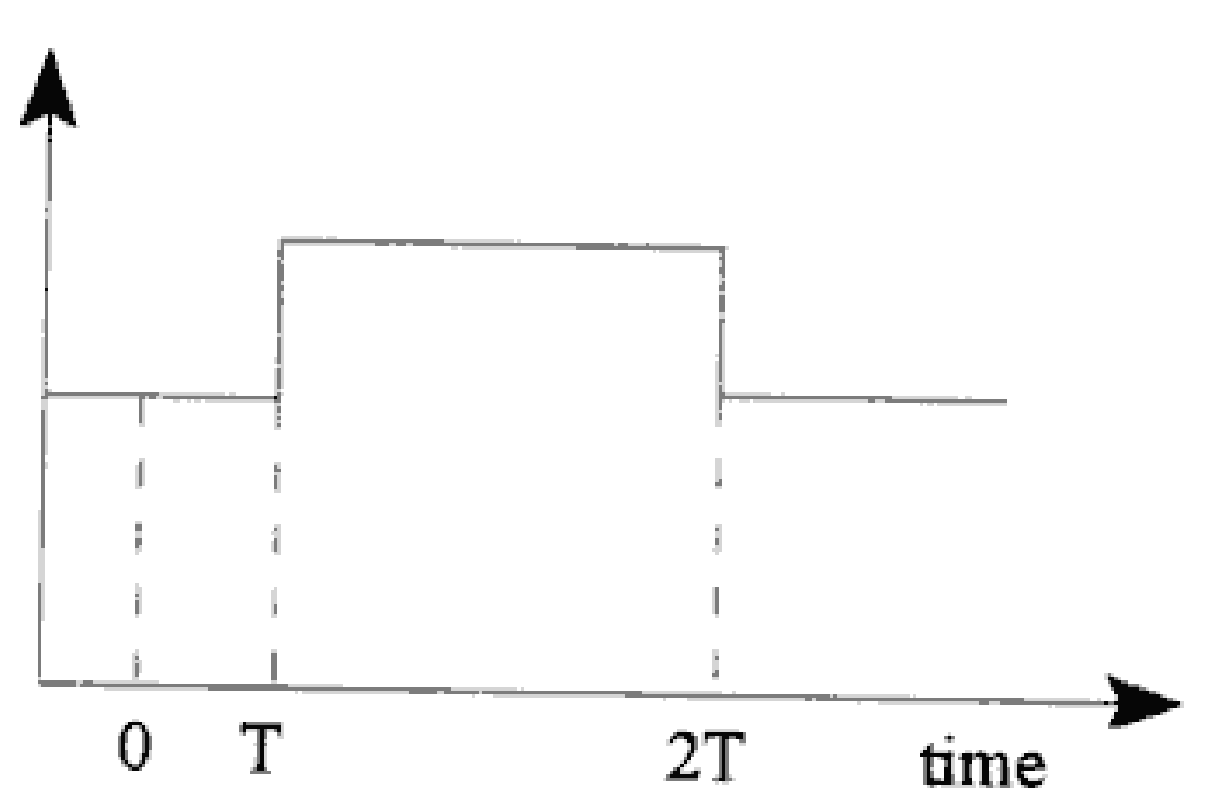

D. Credit

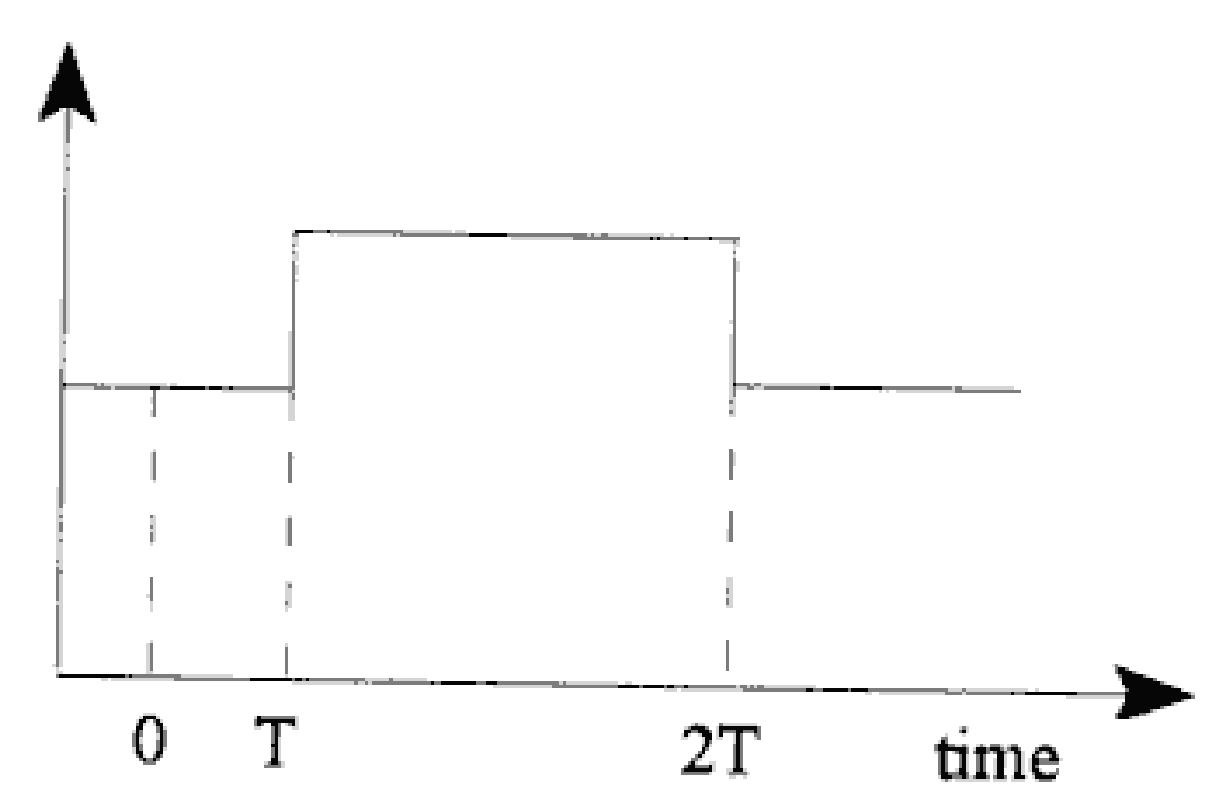

F. Spread

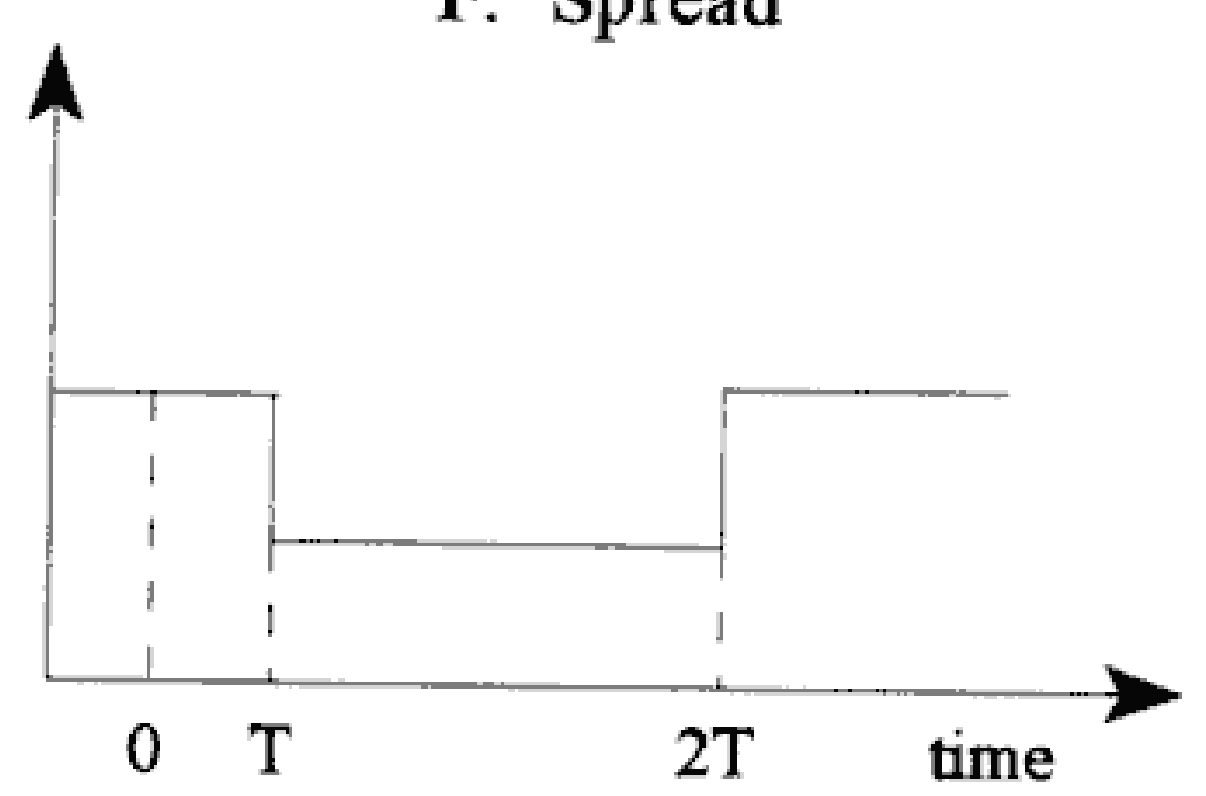


Figure 3: Evolution of Real Credit to the Private Sector in Chile and Mexico

\section{A: CHILE}

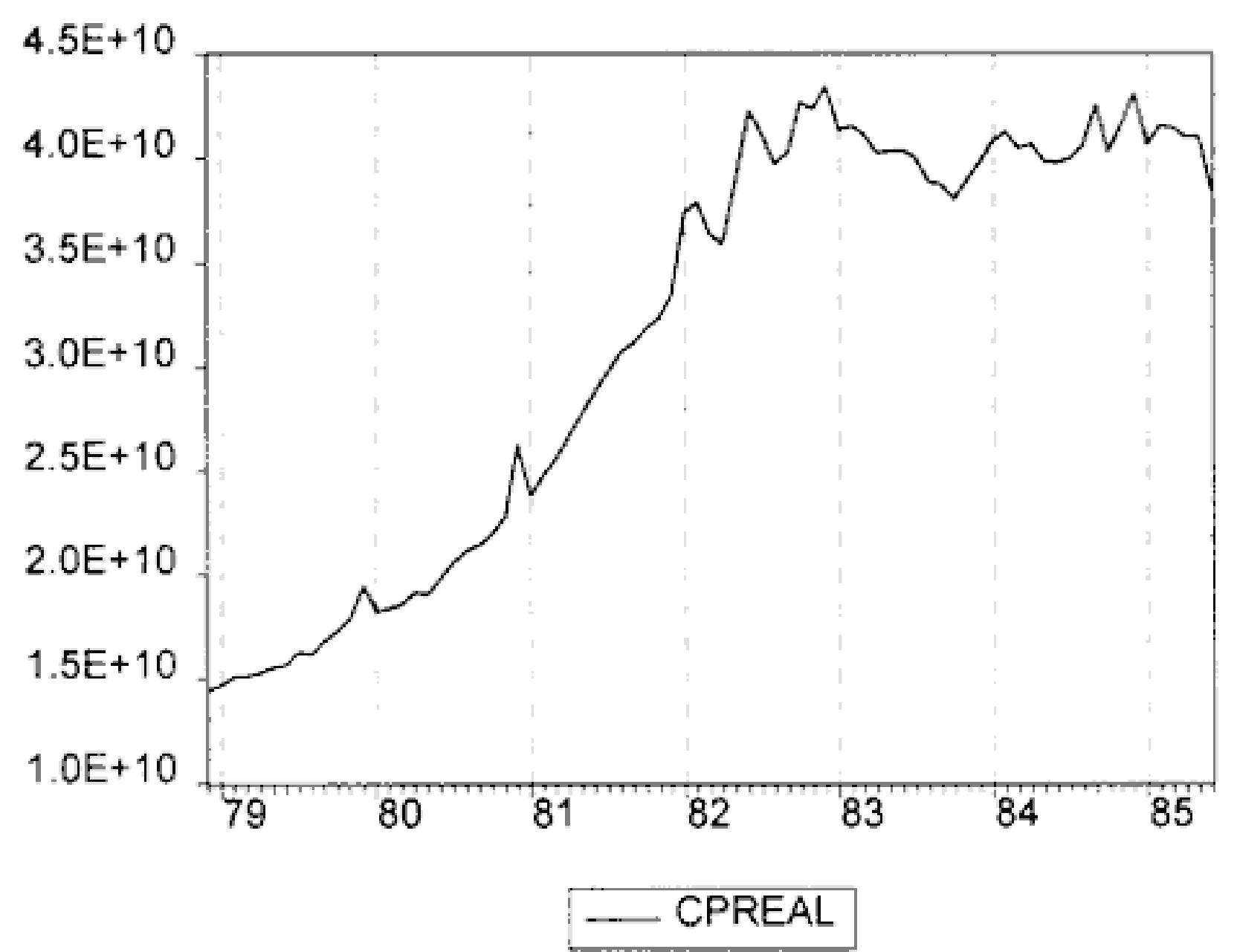

B: MEXICO

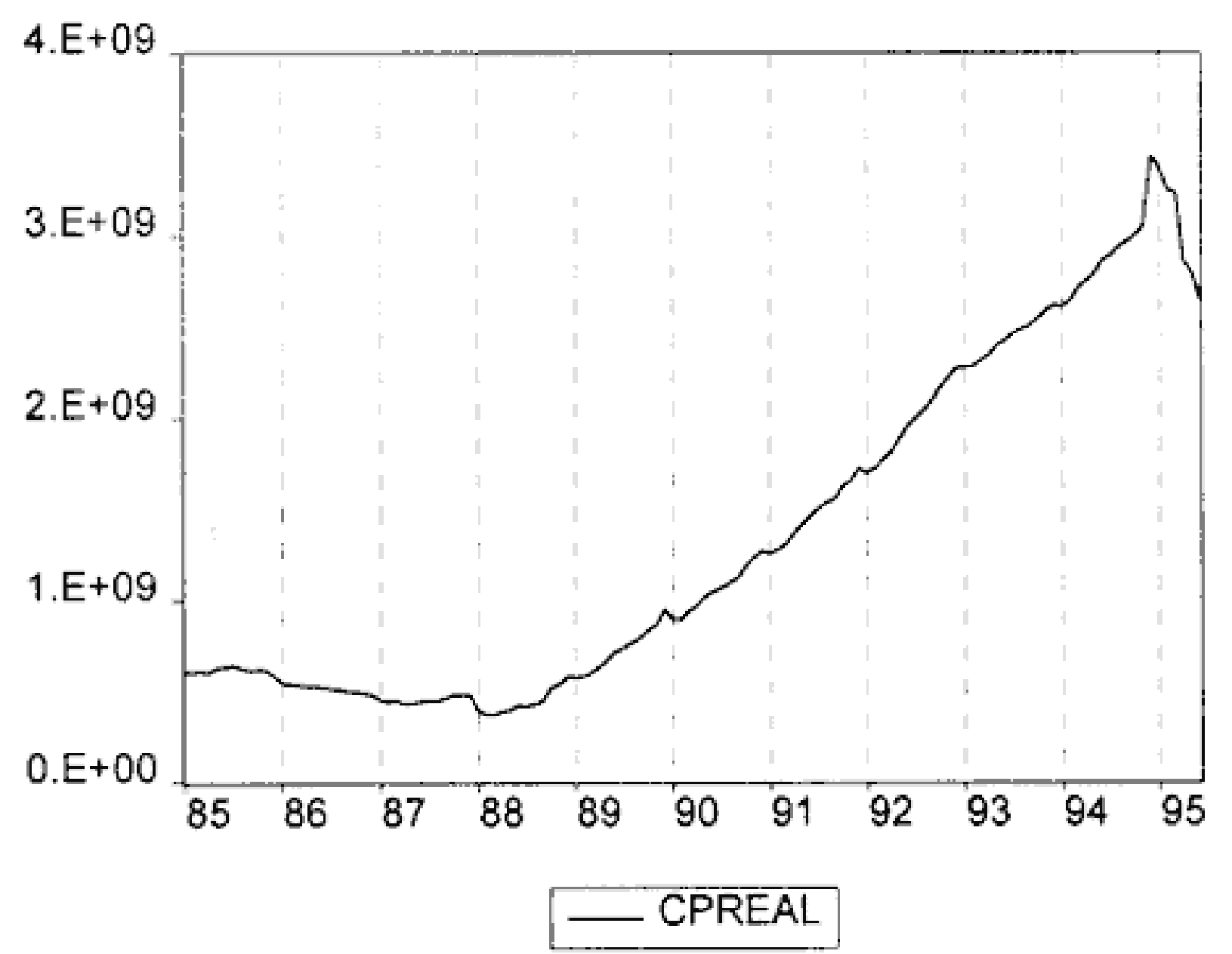


Figure 4: World Interest Rates and Selected Variables in Chile
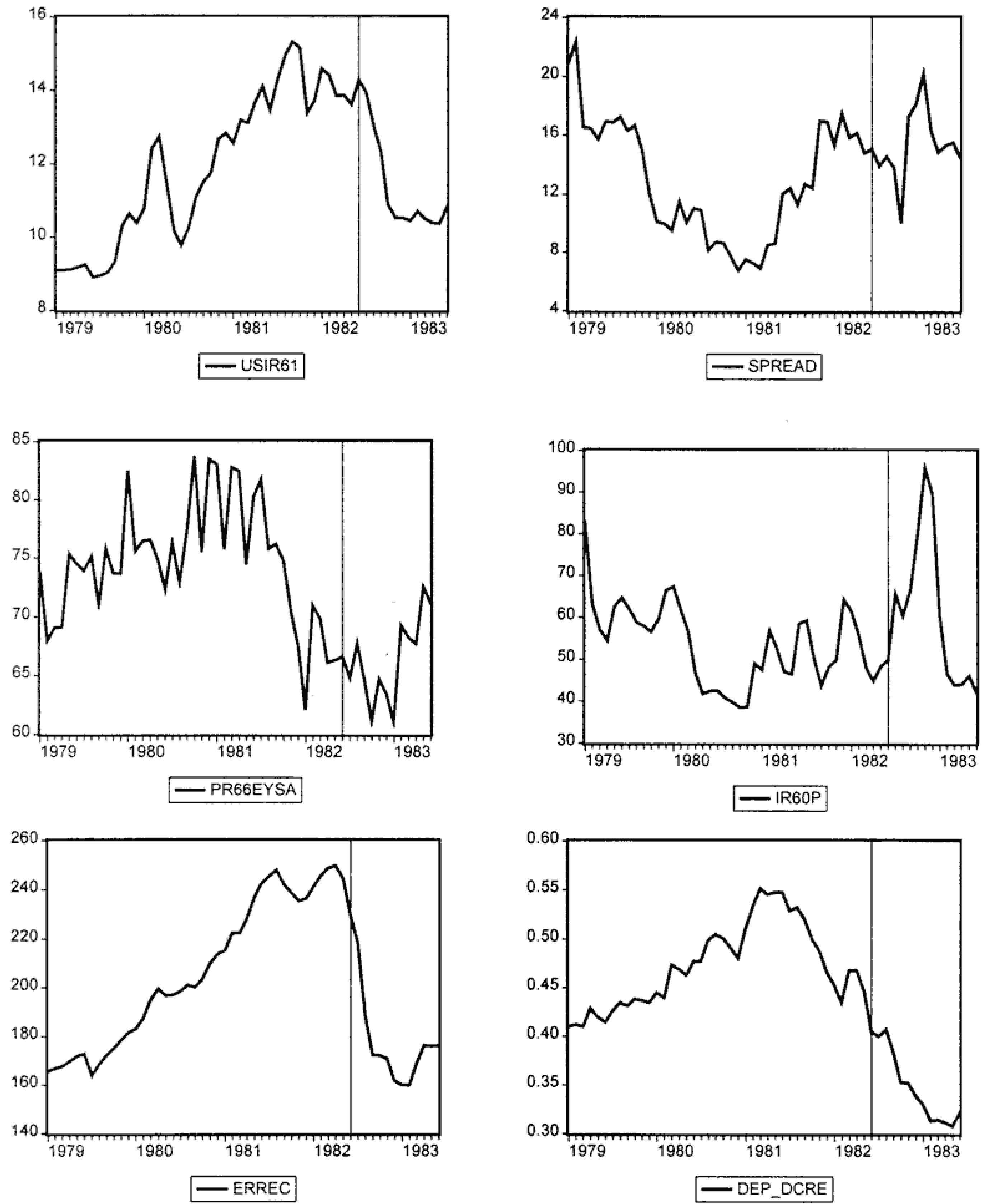
Figure 5: World Interest Rates and Selected Variables in Mexico
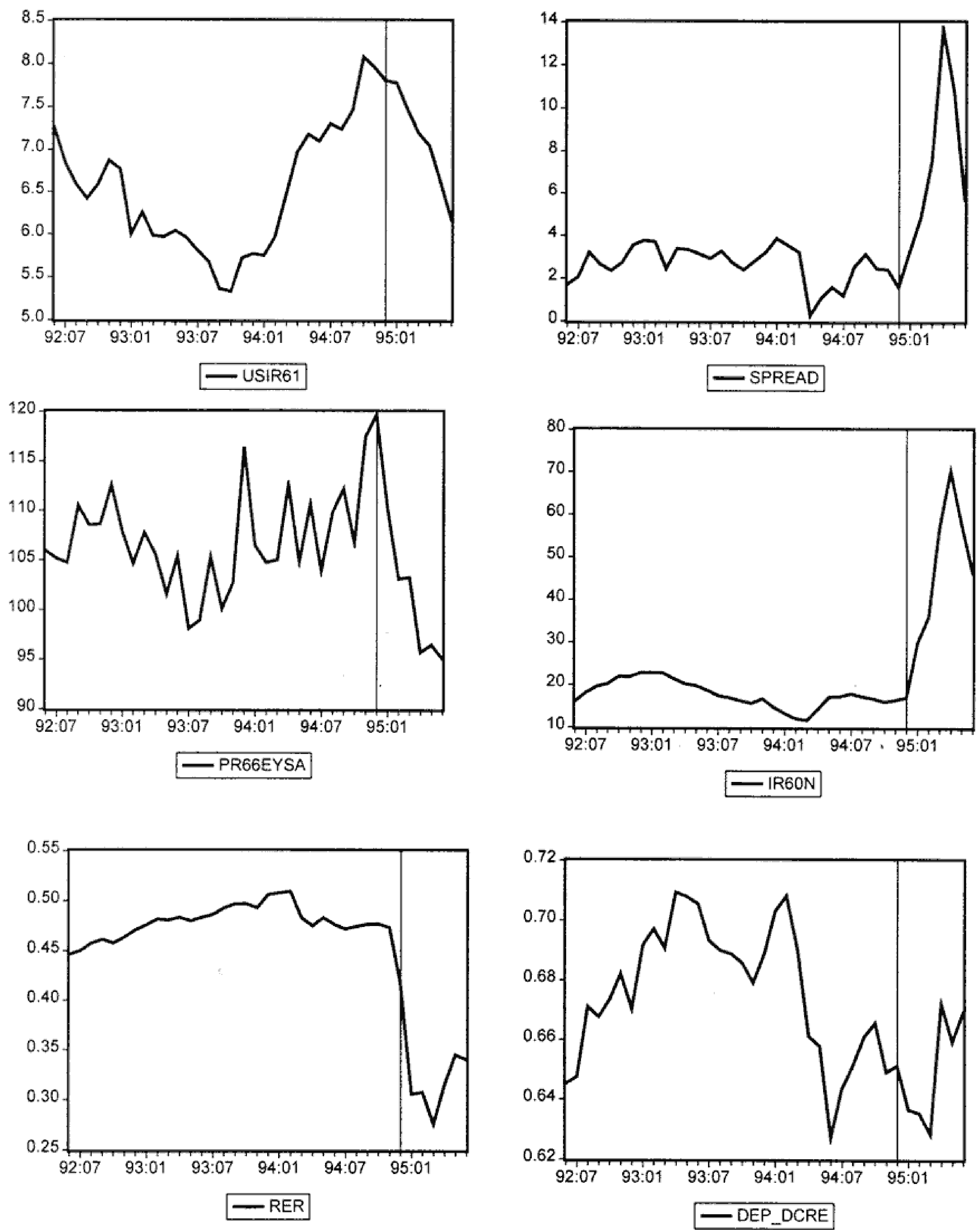
Figure 6: Impulse Response of Domestic Interest Rates in Chile Response of IR60PCY to One S.D. Innovations

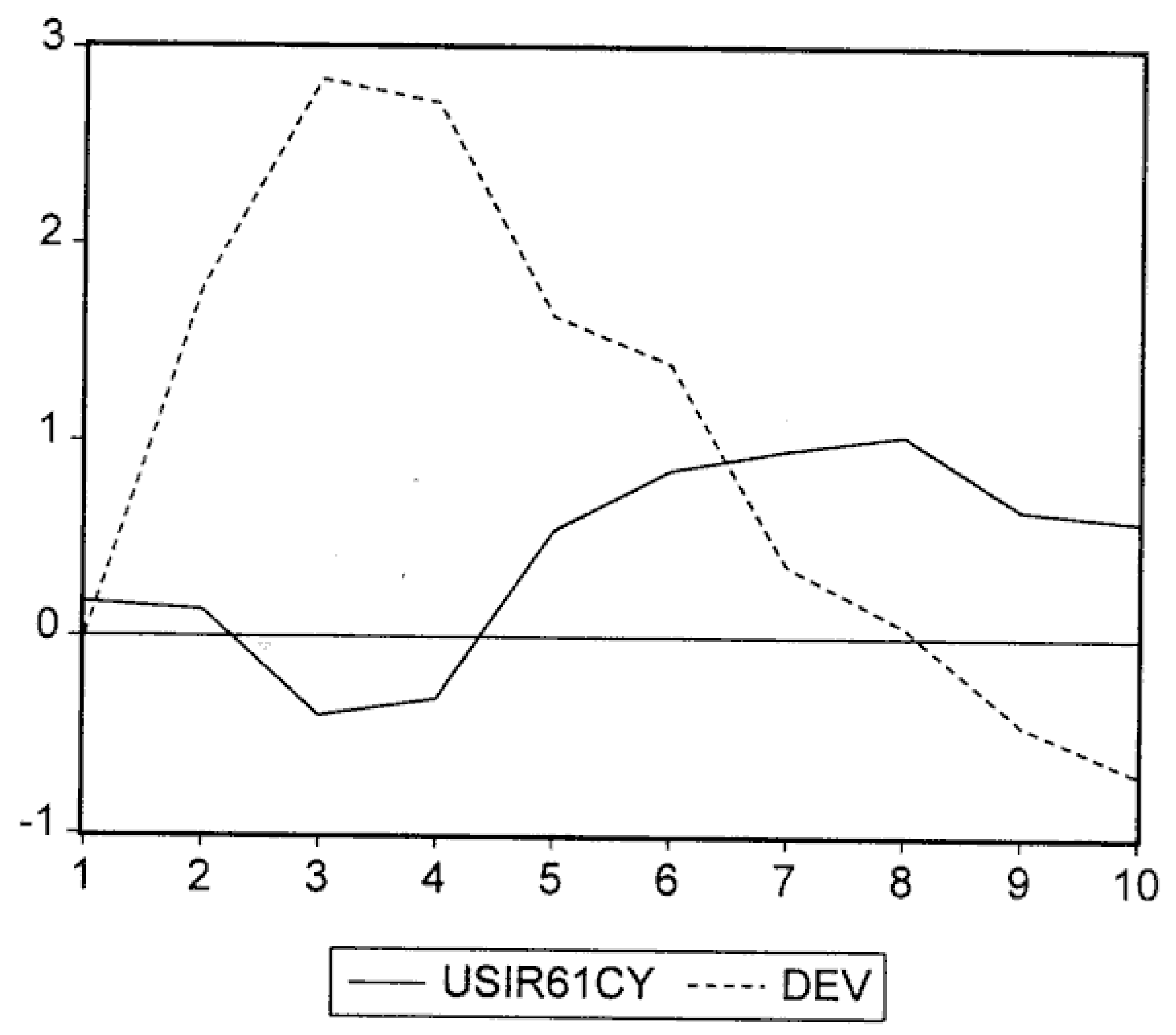


Figure 6A: Impulse Response of Domestic Interest Rates in Mexico Response of IR60NCY to One S.D. Innovations

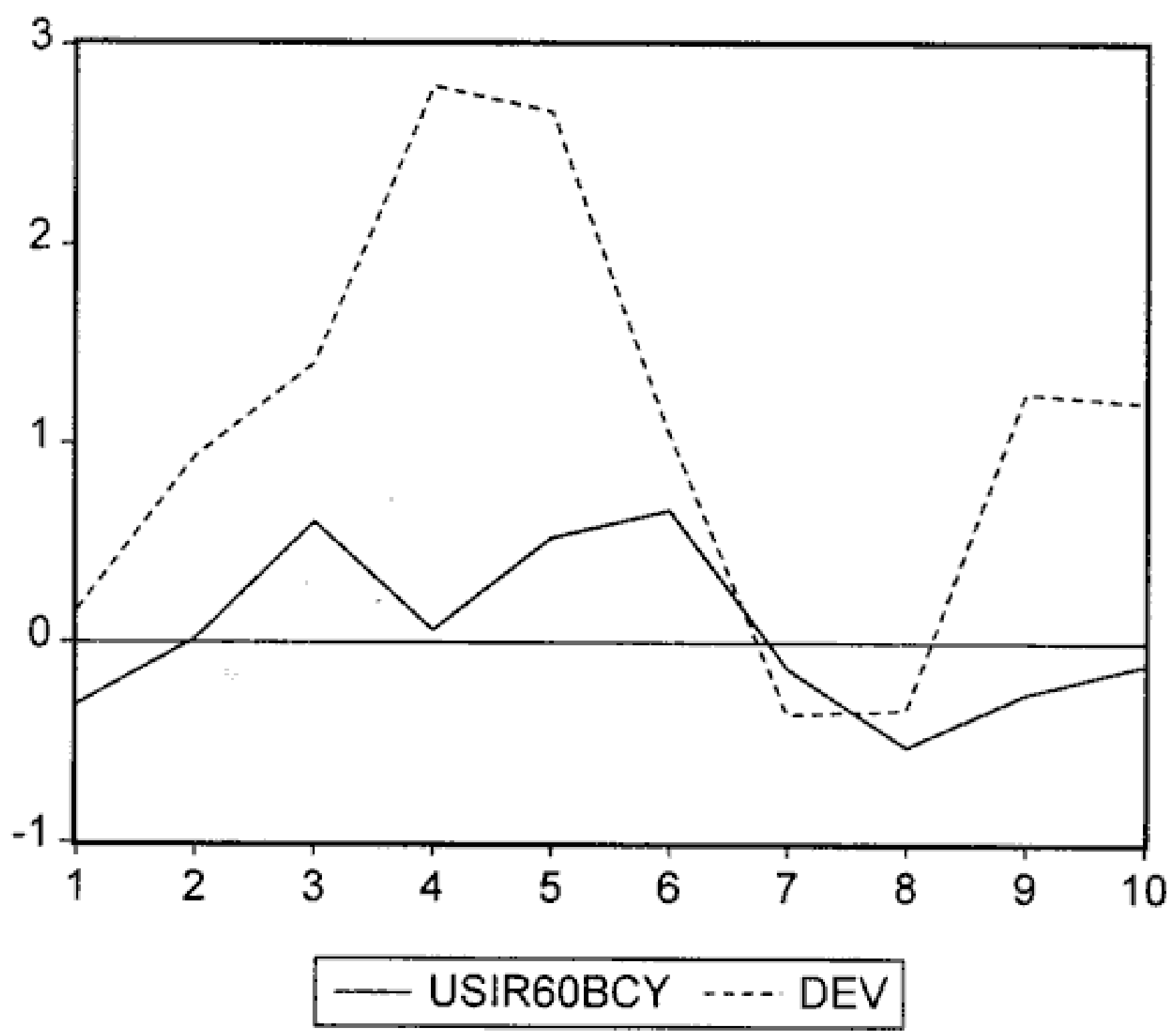


FIGURE 7: Impulse Response Functions for Chile

Response of PROCY to One S.D. Innovations

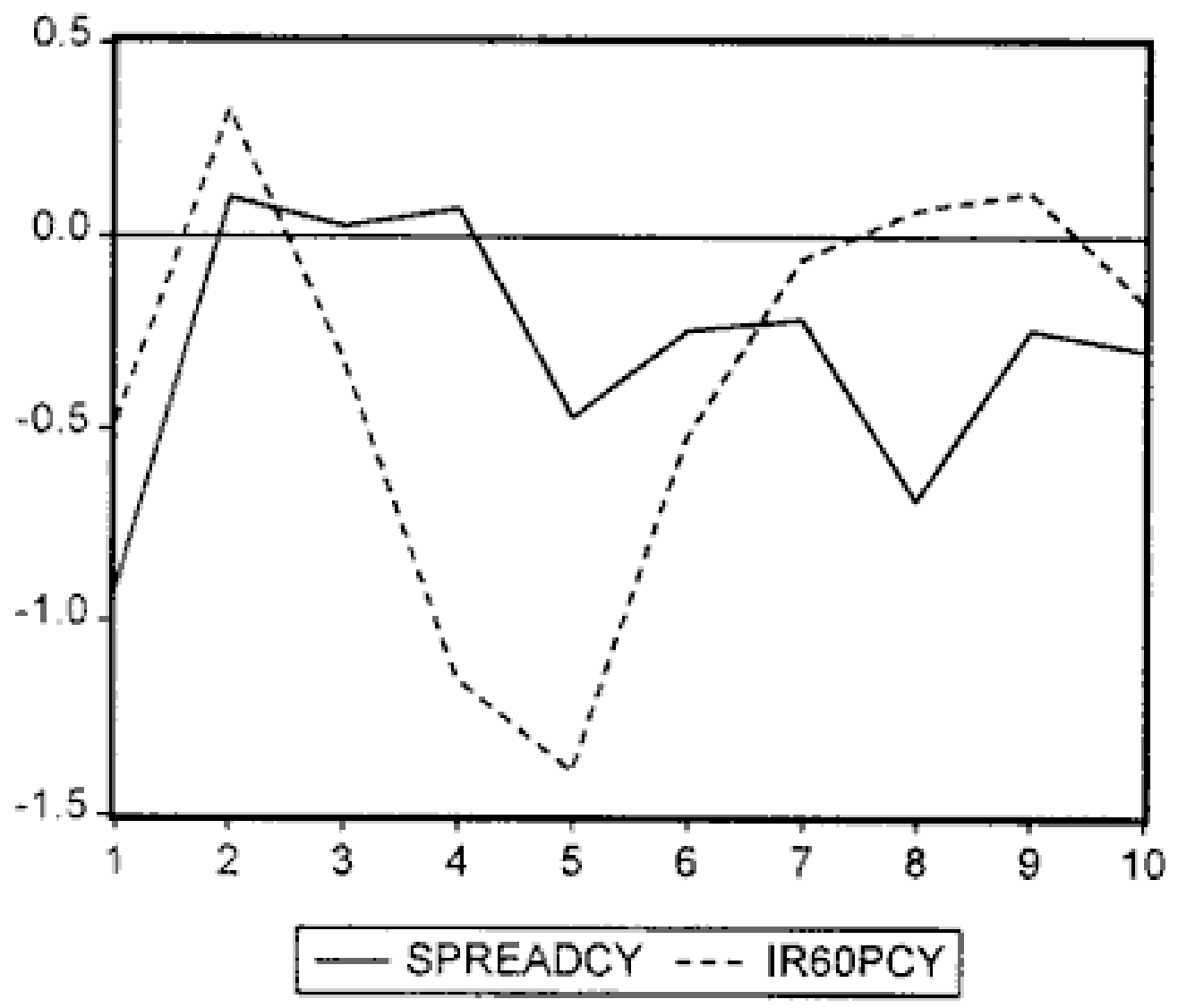

Response of DE_DCY to One S.D. Innovations

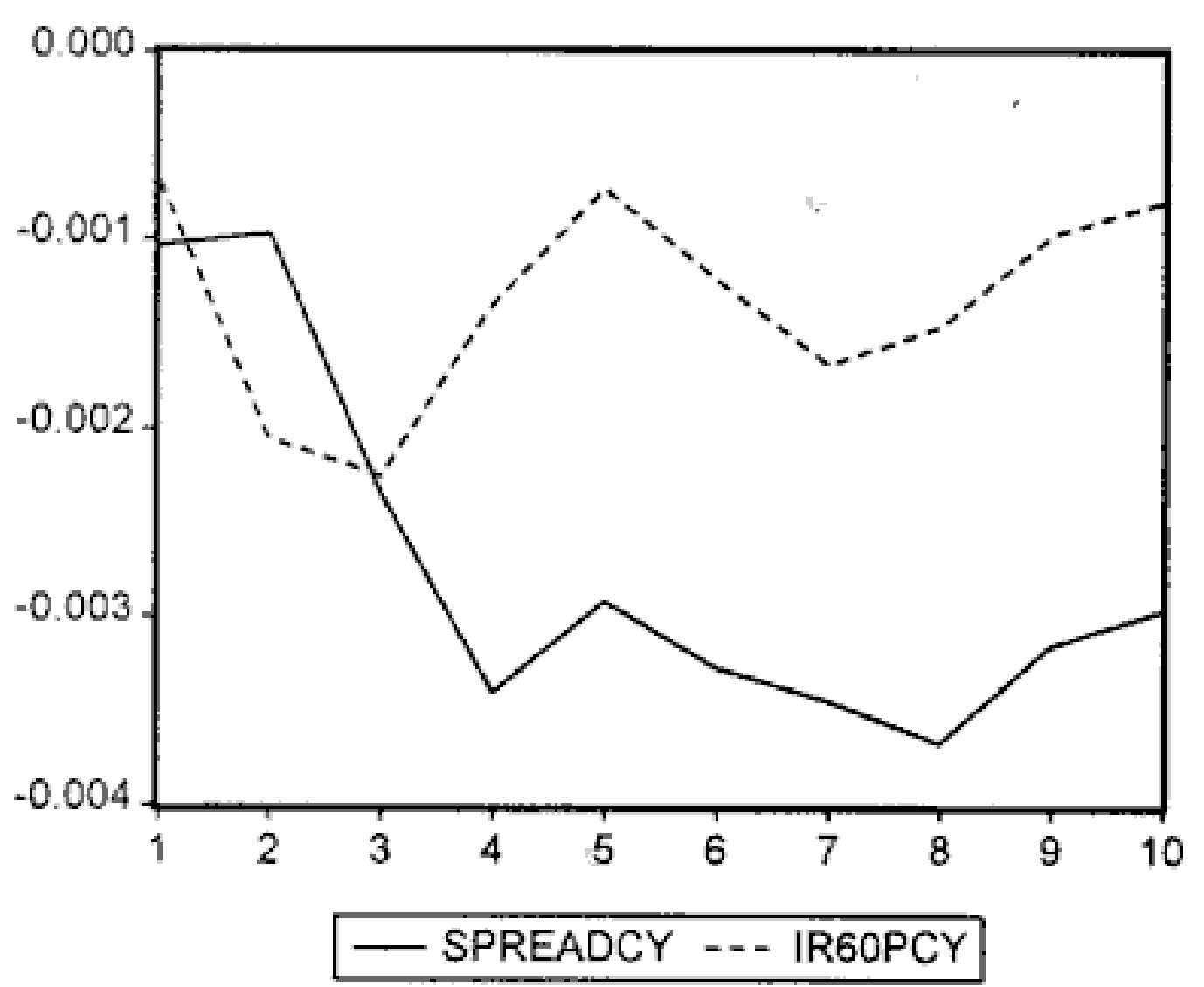

Response of SPREADCY to One S.D. Innovations

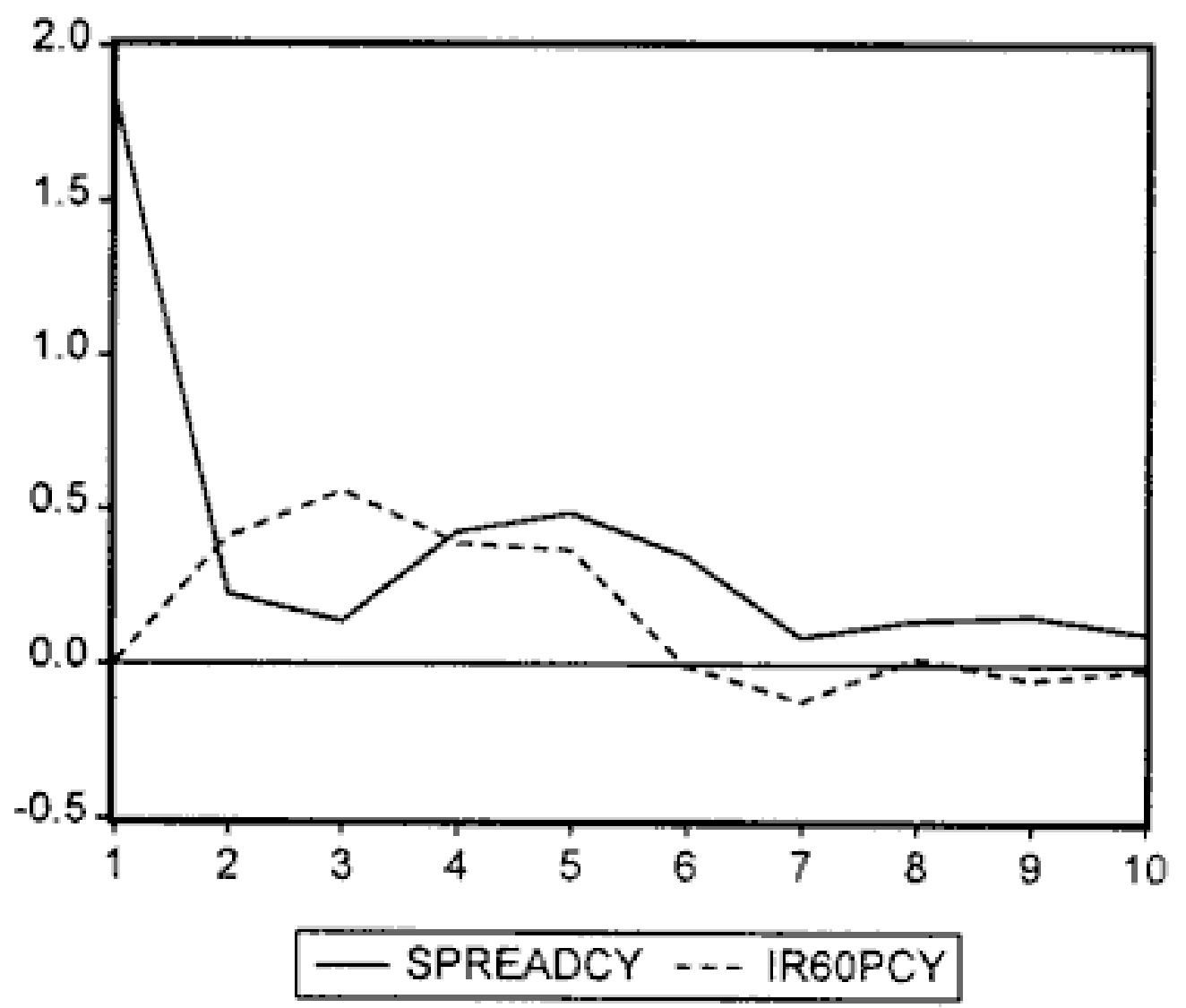

Response of ERREC to One S.D. Innovations

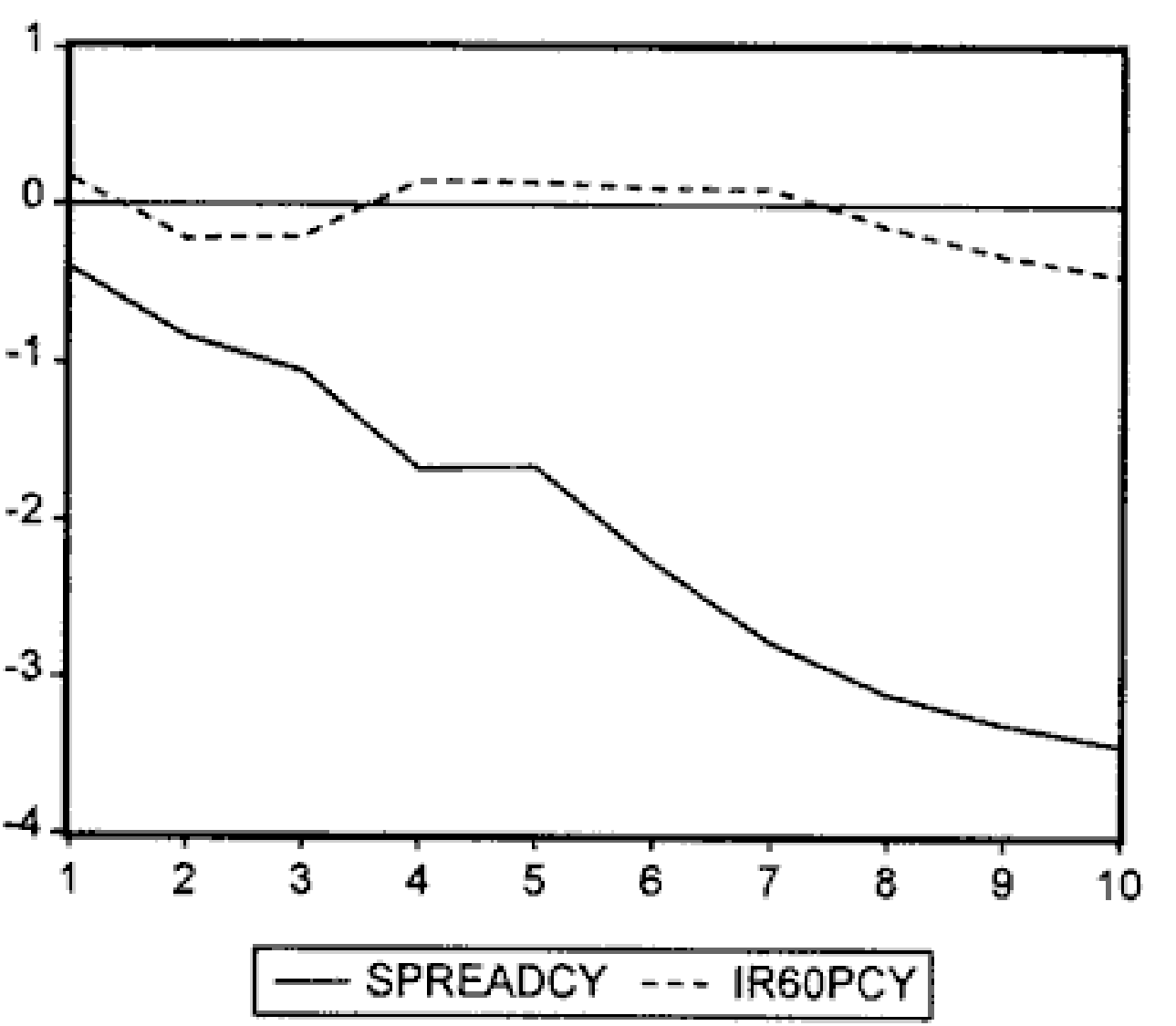


FIGURE 8: Impulse Response Functions for Mexico

Response of PROCY to One S.D. Innovations

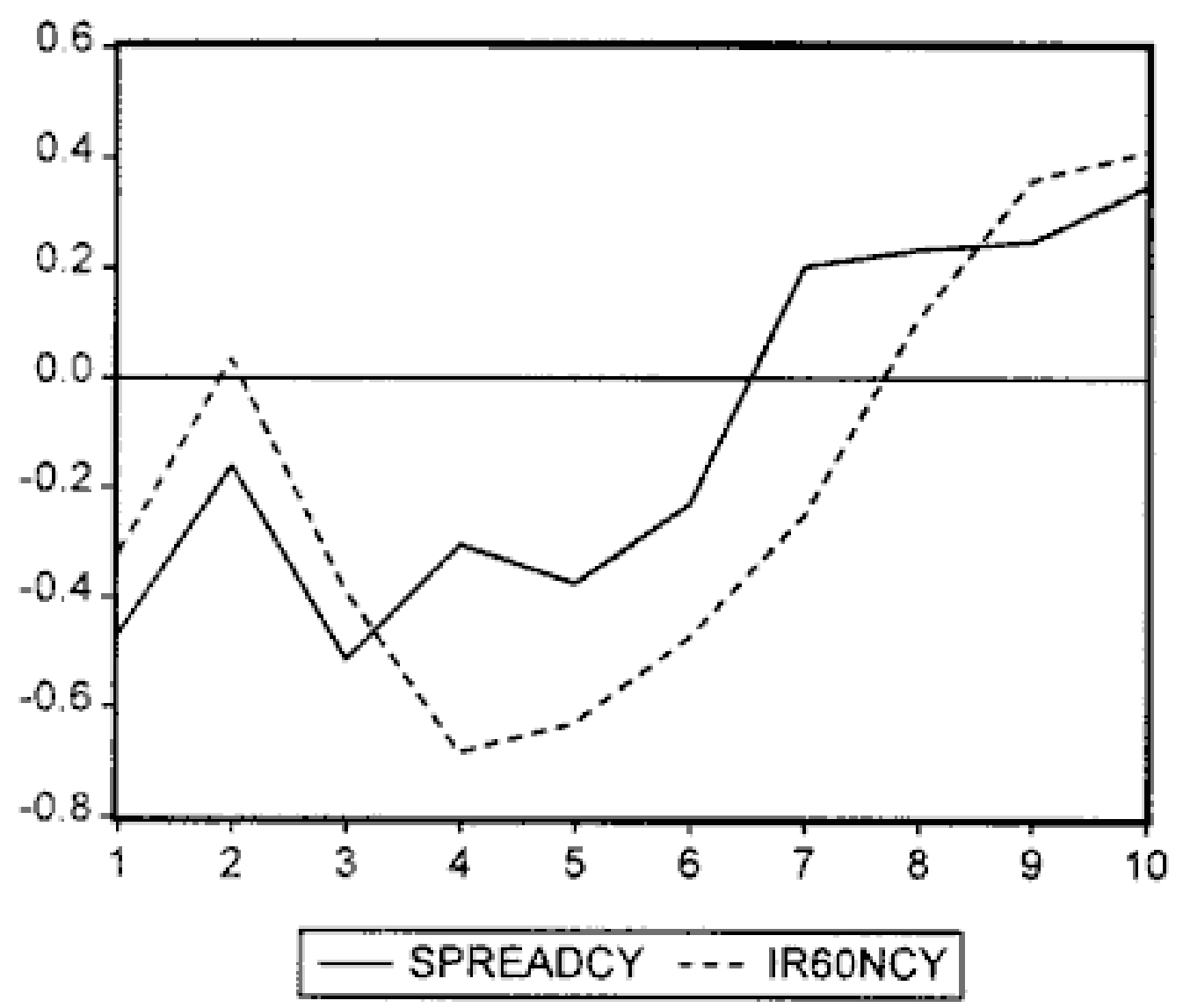

Response of DE_DCY to One S.D. Innovations

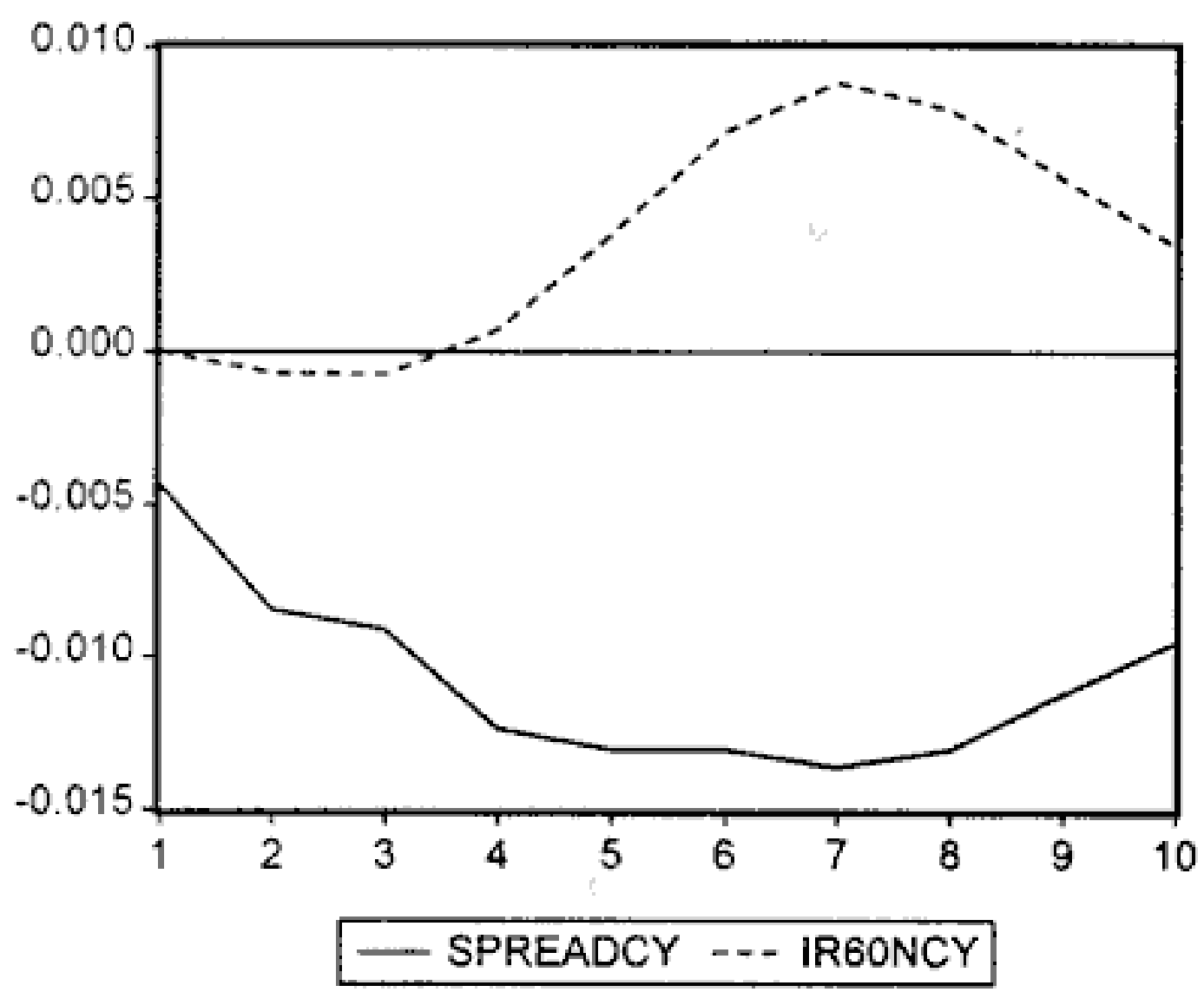

Response of SPREADCY to One S.D. Innovations

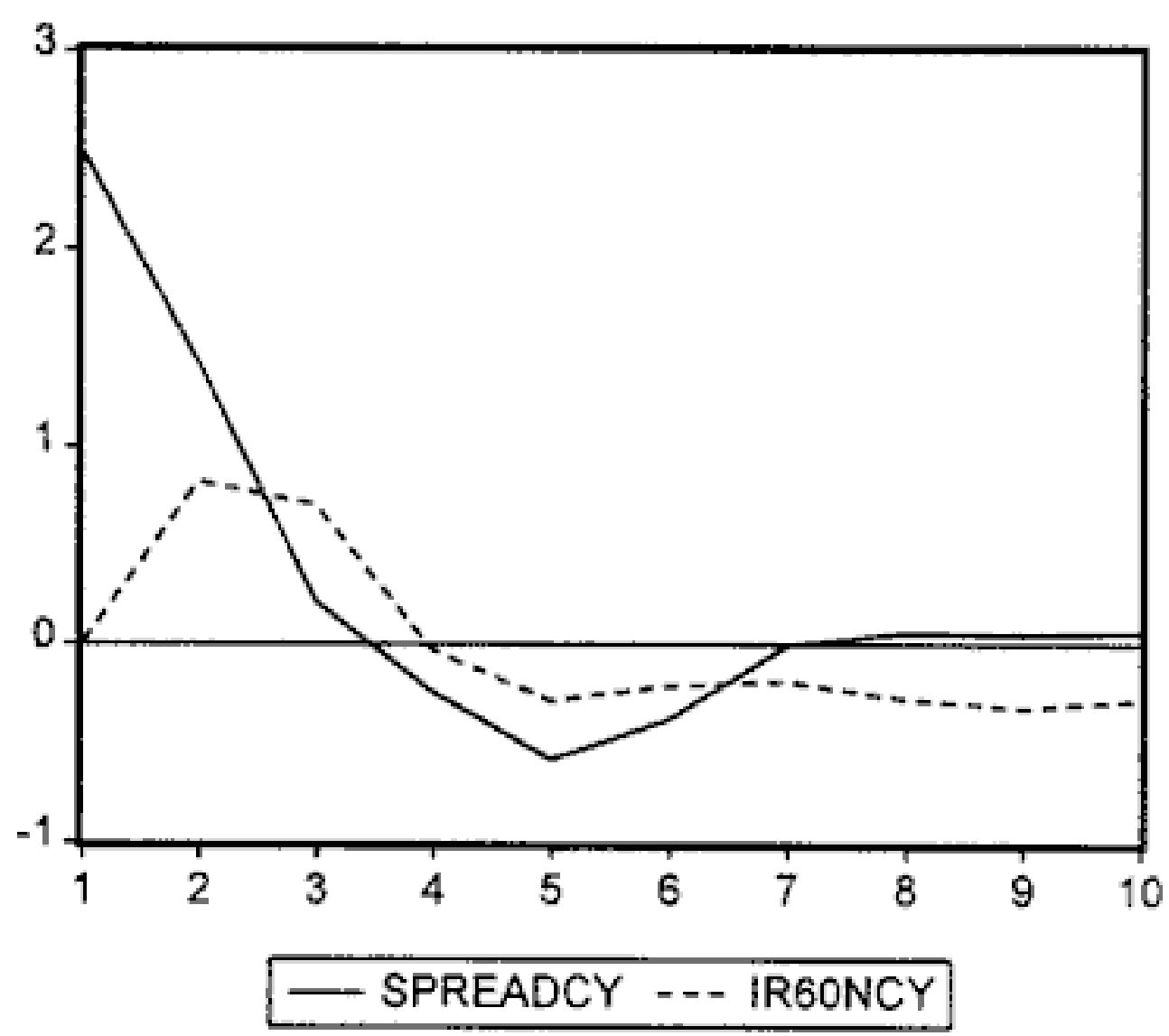

Response of ERERCY to One S.D. Innovations

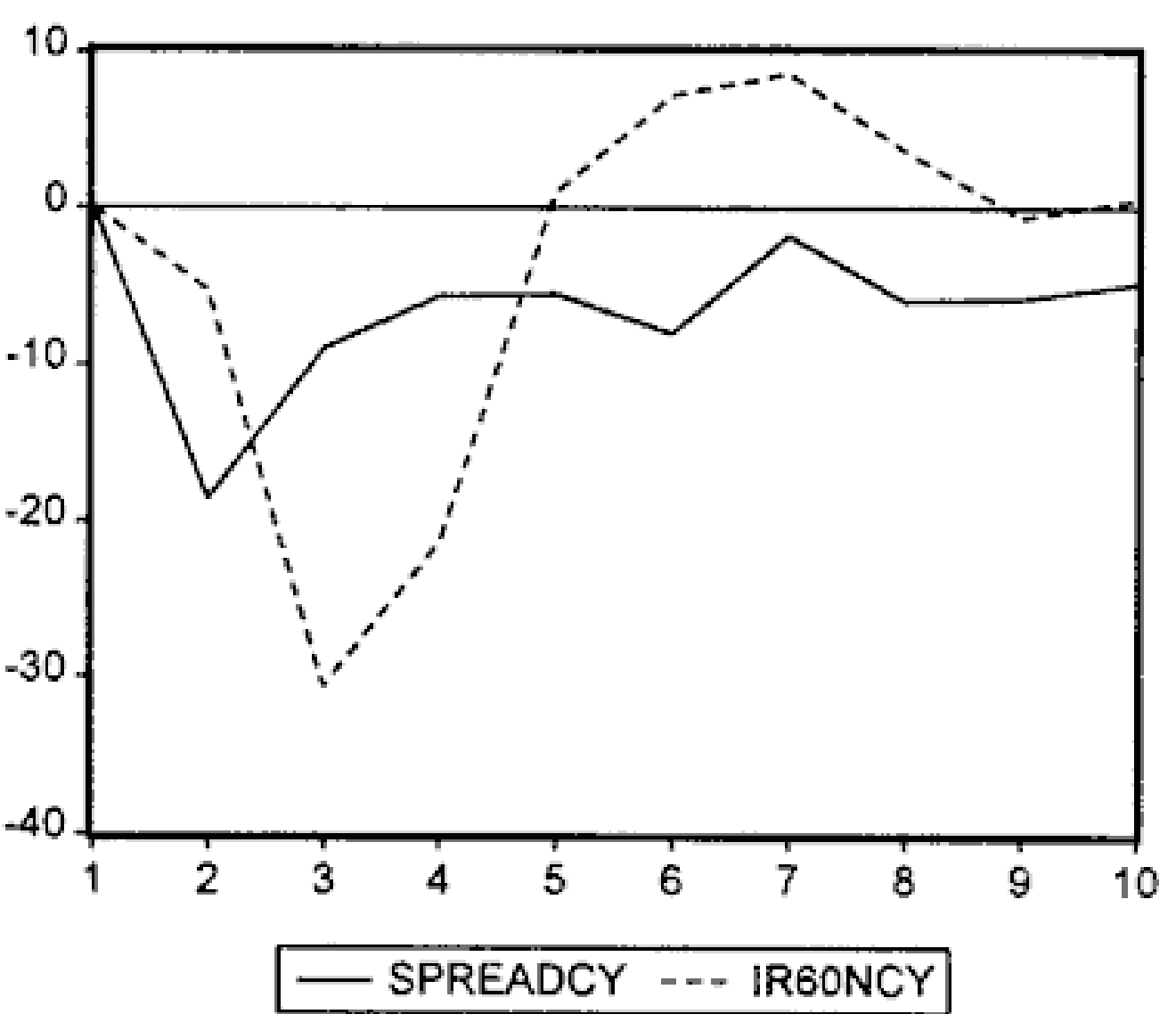


Table 1. The Chilean and Mexican Structural Reforms: An Overview

\begin{tabular}{|l|l|l|}
\hline & CHILE & MEXICO \\
\hline $\begin{array}{l}\text { Approximate date of reforms } \\
\text { initiation }\end{array}$ & 1974-1975 & 1985-1986 \\
\hline Trade Liberalization & $\begin{array}{l}\text { Major unilateral opening } \\
\text { during 1975-79. All } \\
\text { quantitative restrictions } \\
\text { eliminated; uniform tariff of } \\
10 \% \text { established. Temporary } \\
\text { hike in tariffs in mid 1980s; } \\
\text { since 1987 uniform import } \\
\text { tariff of 11\%. }\end{array}$ & $\begin{array}{l}\text { Soverage of nontariff barriers } \\
\text { reduced from 90\% of imports } \\
\text { in 1986 to 19\% of imports in } \\
\text { 1994. Tariff range reduced to } \\
\text { 0-20\%, with a tariff average } \\
\text { of 13\% in 1994. Joined }\end{array}$ \\
\hline Privatization & $\begin{array}{l}\text { NAFTA in 1994. } \\
\text { Two rounds of privatization: } \\
\text { firs-9 and 1984-9. During } \\
\text { first round, banks were } \\
\text { privatized first, followed by } \\
\text { manufacturing firms. First } \\
\text { round ended in crisis in 1982 } \\
\text { with a number of major } \\
\text { banks being nationalized. } \\
\text { During second round, effort } \\
\text { was made to establish } \\
\text { regulatory framework before } \\
\text { firms and banks were sold. } \\
\text { By 1994 all but a handful of } \\
\text { firms had been privatized. } \\
\text { By that time, approximately } \\
\text { 96\% of state-owned } \\
\text { enterprises had been } \\
\text { privatized. Some major } \\
\text { firms, including the giant } \\
\text { copper producer CODELCO, } \\
\text { remains under government } \\
\text { control. }\end{array}$ & $\begin{array}{l}\text { Majorization program } \\
\text { started in 1984 and } \\
\text { intensified in 1989. Small } \\
\text { manufacturing firms } \\
\text { privatized first, public } \\
\text { utilities next, followed by } \\
\text { banks. Effort made to } \\
\text { implement modern regulatory } \\
\text { framework. In spite of this, } \\
\text { regulation and supervision } \\
\text { remained weak, especially in } \\
\text { the banking sector. Effort to } \\
\text { assign individual property } \\
\text { rights on land has been } \\
\text { significantly slowed down by } \\
\text { legal and logistical } \\
\text { difficulties. By 1994, } \\
\text { approximately 80\% of state- } \\
\text { owned enterprises had been } \\
\text { privatized. Oil-related firms, } \\
\text { including PEMEX, remained } \\
\text { in the government sector. }\end{array}$ \\
\hline
\end{tabular}




\begin{tabular}{|c|c|c|}
\hline Fiscal Reform & $\begin{array}{l}\text { Major tax reform in } 1975 . \\
\text { Value added tax introduced. } \\
\text { Personal and corporate } \\
\text { income taxes consolidated. } \\
\text { Significant improvement in } \\
\text { administrative capacity. } \\
\text { Fiscal accounts balanced } \\
\text { since } 1977 \text {. Tax rates revised } \\
\text { in mid 1980s in order to } \\
\text { encourage savings. }\end{array}$ & $\begin{array}{l}\text { Tax reform initiated in } 1985 \text {. } \\
\text { Major adjustment } \\
\text { accomplished -- primary } \\
\text { fiscal deficit of } 6 \% \text { of GDP } \\
\text { was transformed into a } \\
\text { surplus exceeding } 7 \% \text { of } \\
\text { GDP. Fiscal stance was } \\
\text { somewhat loosened in } 1994 \\
\text { as the presidential elections } \\
\text { approached. }\end{array}$ \\
\hline $\begin{array}{l}\text { Financial and Banking } \\
\text { Reforms }\end{array}$ & $\begin{array}{l}\text { Sweeping reform was begun } \\
\text { in } 1975 \text { with the privatization } \\
\text { of banks. Interest rate } \\
\text { controls and forced credit } \\
\text { allocation were eliminated. } \\
\text { Reserve requirements were } \\
\text { drastically reduced and entry } \\
\text { into the banking sector was } \\
\text { encouraged. Securities } \\
\text { markets received a major } \\
\text { boost as a result of social } \\
\text { security reform. Supervisory } \\
\text { framework weak until mid } \\
1980 \text { s; significantly } \\
\text { strengthened since then. }\end{array}$ & $\begin{array}{l}\text { Important reform initiated in } \\
1988 \text {, when interest rates } \\
\text { were freed. Some directed } \\
\text { credit and subsidized loans } \\
\text { still handled by development } \\
\text { banks. Banks gradually } \\
\text { privatized after 1990. Buyers } \\
\text { paid several times book } \\
\text { values. Reserve requirements } \\
\text { fully eliminated on peso- } \\
\text { denominated deposits. Banks } \\
\text { allowed to hold equity } \\
\text { positions in manufacturing } \\
\text { and other firms. Very weak } \\
\text { regulatory and supervisory } \\
\text { capacity. Banks developed } \\
\text { quickly a sizable portfolio of } \\
\text { non-performing loans. }\end{array}$ \\
\hline Social Security & $\begin{array}{l}\text { Insolvent pay-as-you-go } \\
\text { system replaced by } \\
\text { individually capitalized } \\
\text { system run by private } \\
\text { administrators. Health } \\
\text { system transformed into two- } \\
\text { tier system: a basic one for } \\
\text { lower income people and an } \\
\text { insurance-based system for } \\
\text { most workers. }\end{array}$ & $\begin{array}{l}\text { No significant reform until } \\
\text { 1994. Major reform } \\
\text { undertaken in } 1996 .\end{array}$ \\
\hline
\end{tabular}




\begin{tabular}{|l|l|l|}
\hline Labor Markets & $\begin{array}{l}\text { Reformed in 1981. } \\
\text { Severance payments capped, } \\
\text { conflict resolution system } \\
\text { redesigned. Taxes on labor } \\
\text { reduced significantly. Most } \\
\text { barriers to entry eliminated. } \\
\text { Labor legislation reformed in } \\
\text { 1991, but main features of } \\
\text { 1981 reform maintained. }\end{array}$ & \\
\hline
\end{tabular}

Source: Edwards and Edwards (1991), Aspe (1995) and Edwards (1995). 
Table 2. Exchange Rate Policy

A. Chile, $1975-1982$

\begin{tabular}{|l|l|}
\hline April 1975 - May 1976 & $\begin{array}{l}\text { Crawling peg: nominal exchange rate } \\
\text { adjusted at approximately the same rate as } \\
\text { lagged inflation }\end{array}$ \\
\hline June 1976 - January 1978 & $\begin{array}{l}\text { Crawling peg continued, but with } 10 \% \\
\text { revaluations on June 1976 and March } 1977\end{array}$ \\
\hline February 1978 - June 1979 & $\begin{array}{l}\text { The tablita system: preannounced rates of } \\
\text { devaluations set below the ongoing rate of } \\
\text { inflation }\end{array}$ \\
\hline June 1979 - June 1982 & Fixed peg set at 39 pesos per dollar \\
\hline
\end{tabular}

\section{B. Mexico, 1988 - 1994}

\begin{tabular}{|c|c|}
\hline February-December 1988 & $\begin{array}{l}\text { Fixed nominal exchange rate at } 2281 \text { pesos } \\
\text { per dollar }\end{array}$ \\
\hline January-December 1989 & $\begin{array}{l}\text { Preannounced rate of devaluation set at } 1 \\
\text { peso per day }\end{array}$ \\
\hline January-December 1990 & $\begin{array}{l}\text { Preannounced rate of crawl of nominal } \\
\text { exchange rate set at } 80 \text { cents per day }\end{array}$ \\
\hline December 1990-November 1991 & $\begin{array}{l}\text { Preannounced rate of crawl of nominal } \\
\text { exchange rate set at } 40 \text { cents per day }\end{array}$ \\
\hline November 1991-October 1992 & $\begin{array}{l}\text { Exchange rate band adopted. Floor is fixed at } \\
3050 \text { pesos per dollar, while ceiling slides at } \\
20 \text { cents per day }\end{array}$ \\
\hline November 1992-December 19, 1994 & $\begin{array}{l}\text { Rate of devaluation of band's ceiling is } \\
\text { accelerated to } 40 \text { old cents per day ( } 0.0004 \\
\text { new pesos). Bank of Mexico intervened } \\
\text { through March } 1994 \text { in order to maintain the } \\
\text { dollar/peso rate within narrower } \\
\text { (confidential) "inner" band }\end{array}$ \\
\hline December 20-December 21, 1994 & Ceiling of band increased by 15 percent \\
\hline December 22,1994 onwards & Floating exchange rate \\
\hline
\end{tabular}


Table 3: Phillips-Perron Unit Root Tests

\begin{tabular}{|l|l|l|l|l|}
\hline & CHILE & CHILE & MEXICO & MEXICO \\
\hline & Levels & 1 st Differences & Levels & 1st Differences \\
\hline Real Credit & -1.12 & $-15.30^{*}$ & -2.14 & $-8.99^{*}$ \\
\hline Real Deposits & -0.02 & $-21.54^{*}$ & -2.07 & $-9.24^{*}$ \\
\hline Deposit/Credit & -0.52 & $-13.21^{*}$ & -2.48 & $-7.13^{*}$ \\
\hline Industrial Prod. & -2.95 & $-43.13^{*}$ & -2.50 & $-18.14^{*}$ \\
\hline $\begin{array}{l}\text { Lending Interest } \\
\text { Rates }\end{array}$ & $-5.23^{*}$ & $-27.18^{*}$ & $-5.13^{*}$ & $-13.71^{*}$ \\
\hline $\begin{array}{l}\text { Borrowing } \\
\text { Interest Rates }\end{array}$ & $-5.97^{*}$ & $-23.14^{*}$ & $-4.13^{*}$ & $-5.79^{*}$ \\
\hline Spread & $-8.71^{*}$ & $-38.29^{*}$ & $-3.60^{*}$ & $-14.92^{*}$ \\
\hline $\begin{array}{l}\text { Nominal } \\
\text { Devaluation }\end{array}$ & $-12.21^{*}$ & $-42.54^{*}$ & $-6.81^{*}$ & $-13.44^{*}$ \\
\hline $\begin{array}{l}\text { Real Exchange } \\
\text { Rate }\end{array}$ & $-7.06^{*}$ & $-13.37^{*}$ & $-4.29^{*}$ & $-10.56^{*}$ \\
\hline
\end{tabular}

* Means significance at the $5 \%$ level. 
TABLE 4: Granger Causality Tests*

Null Hypothesis

US interest rates causes

industrial production

Industrial production causes

US interest rates

Spread causes industrial

production

Industrial production causes

spread

Real Deposits causes

industrial production

Industrial production causes

real deposits

Deposits/credit ratio causes

industrial prduction

Industrial production causes

deposit/credit rate

Lending interest rates causes industrial production

Industrial production causes

lending interest rates

Nominal devaluation causes industrial production

Industrial production causes nominal devaluation
CHILE

NO

NO

YES

YES

NO

NO

YES

YES

NO*

NO

NO*

YES

NO

YES

NO

NO

NO

NO

YES

YES

NO

NO

YES

YES

* "No" means that the null hypothesis cannot be rejected. In all cases the level of significance is 5 percent, except when there is an asterisk. In these cases the level of significance is 10 percent. 